NIST Technical Note 1688

U.S. Department of Commerce National Institute of Standards and Technology
Applied Economics Office

Engineering Laboratory

Gaithersburg, MD 20899

\title{
Prototype Residential Buildings for Energy and Sustainability Assessment
}

Joshua D. Kneifel
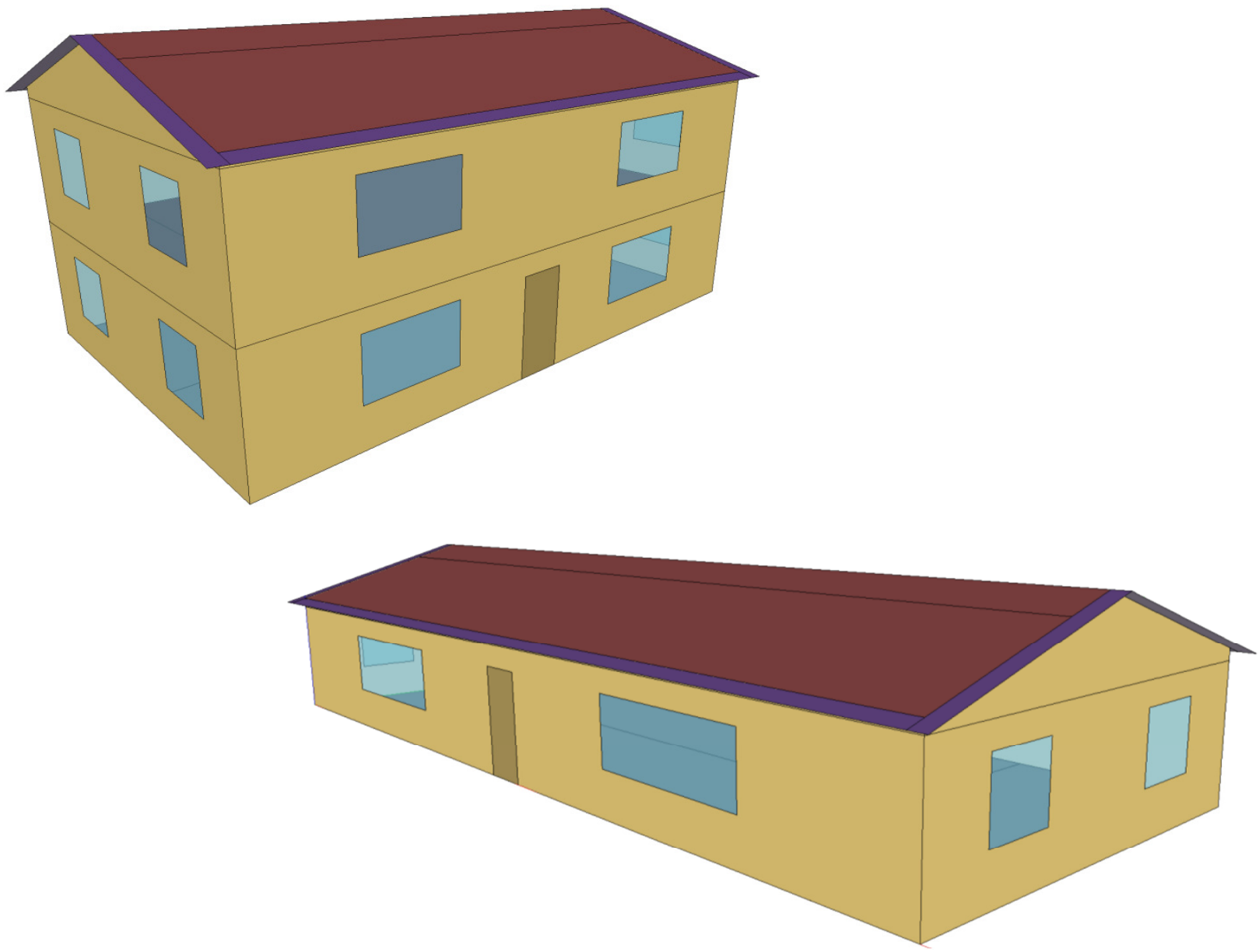



\section{Prototype Residential Buildings for Energy and Sustainability Assessment}

Joshua D. Kneifel

Sponsored by:

National Institute of Standards and Technology

Engineering Laboratory

September 2011

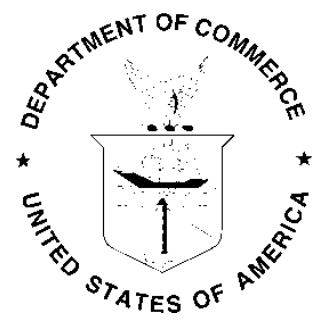

\section{U.S. DEPARTMENT OF COMMERCE}

Gary Locke, Secretary

NATIONAL INSTITUTE OF STANDARDS AND TECHNOLOGY

Dr. Patrick D. Gallagher, Director 


\begin{abstract}
Residential building energy efficiency is becoming increasingly important in U.S. energy policy. Analyzing the effectiveness of potential energy efficiency improvements in the residential sector involves running whole building energy simulations for alternative building designs. Such analysis requires detailed building design characteristics including climate, fuel type, energy technologies, and design improvements. For broad studies of the U.S. residential sector, prototypical designs representing "typical" homes are necessary to provide the basis for this detailed analysis.

This report defines two prototype detached residential house designs based on the 2009 International Energy Code Council (IECC) code. These prototypes can be used as baselines from which to analyze homes built to older IECC codes as well as to estimate the energy savings and sustainability from increasing residential building energy efficiency beyond current energy codes. These prototypes can also be used as a framework for developing additional prototype designs.
\end{abstract}

\title{
Keywords
}

Building economics; life-cycle costing; energy efficiency; residential building; prototype building designs; sustainability assessment 


\section{Preface}

This study was conducted by the Applied Economics Office in the Engineering Laboratory (EL) at the National Institute of Standards and Technology (NIST). The study is designed to document the assumptions and approaches implemented in creating two "prototypical" residential house designs to use as the basis for energy, life-cycle cost, and sustainability estimates for new and existing residential buildings. The intended audience is researchers in the residential building sector concerned with energy efficiency and sustainability.

\section{Disclaimer}

Certain trade names and company products are mentioned in the text in order to adequately specify the technical procedures and equipment used. In no case does such identification imply recommendation or endorsement by the National Institute of Standards and Technology, nor does it imply that the products are necessarily the best available for the purpose. 


\section{Acknowledgements}

The author wishes to thank all those who contributed ideas and suggestions for this report. They include Ms. Barbara Lippiatt and Dr. Robert Chapman of EL's Applied Economics Office, Dr. William Healy of EL's Building Environment Division, Dr. Nicos S. Martys of EL's Materials and Construction Research Division, Philip Kerrigan of Building Science Corporation, and S. Craig Drumheller and Joseph Wiehagen of the National Association of Home Builders (NAHB) Research Center.

\section{Author Information}

Joshua D. Kneifel

Economist

National Institute of Standards and Technology

100 Bureau Drive, Mailstop 8603

Gaithersburg, MD 20899-8603

Tel.: 301-975-6857

Email: joshua.kneifel@nist.gov 


\section{Contents}

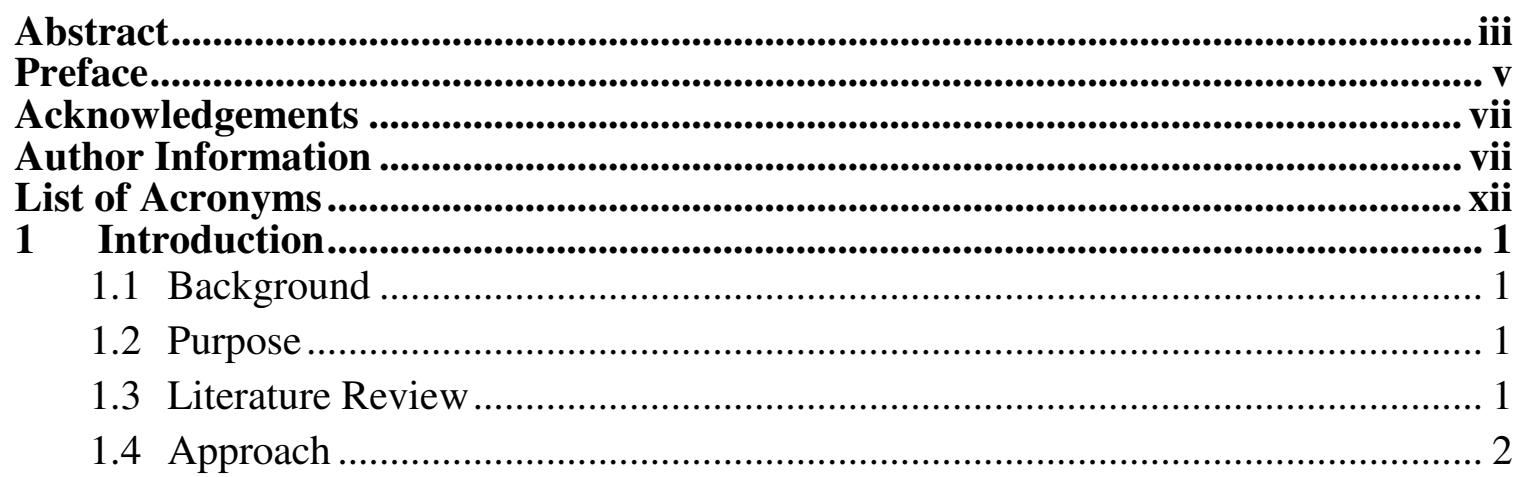

2 One-Story Building Design Specification............................................................. 4

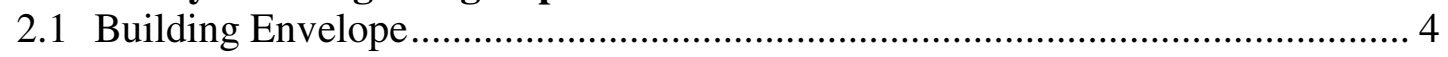

2.1.1 General Assumptions ........................................................................ 4

2.1.2 Climate Zone-Specific Assumptions ..................................................... 7

2.2 Heating, Ventilating, and Air Conditioning Equipment ................................... 9

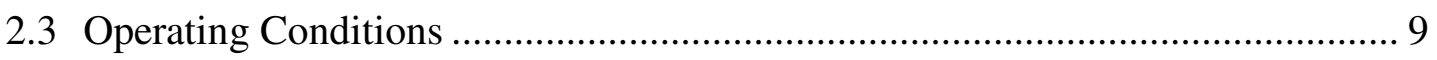

2.4 Mechanical Ventilation and Air Infiltration................................................ 9

2.5 Domestic Hot Water.................................................................................. 10

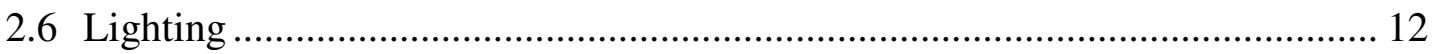

2.7 Appliances and Miscellaneous Electrical Loads ............................................ 14

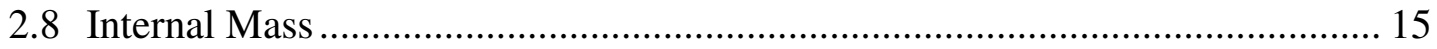

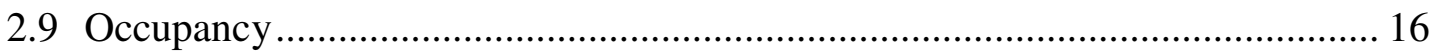

2.10 Internal Heat Gains............................................................................. 17

3 Two-Story Building Design Specification ....................................................... 18

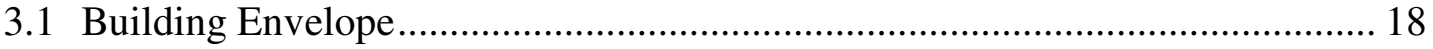

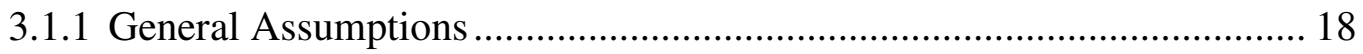

3.1.2 Climate Zone-Specific Assumptions ................................................. 21

3.2 Heating, Ventilating, and Air Conditioning Equipment ................................ 23

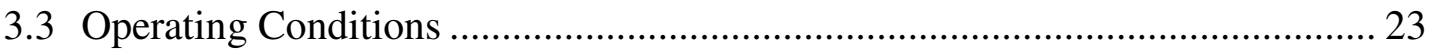

3.4 Air Infiltration and Mechanical Ventilation.................................................... 23

3.5 Domestic Hot Water.................................................................................. 24

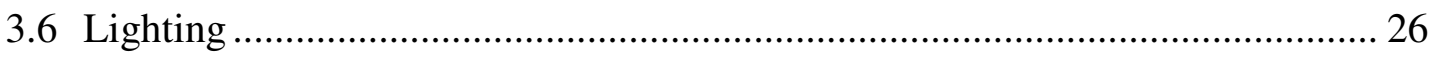

3.7 Appliances and Miscellaneous Electrical Loads ........................................... 28

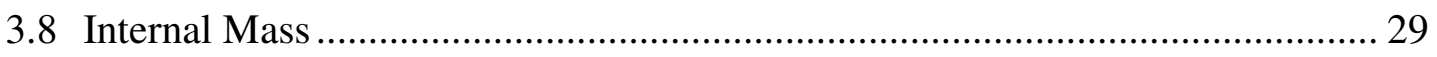

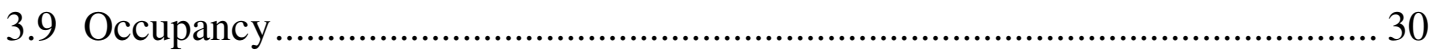

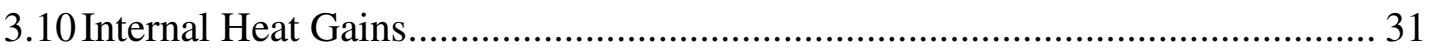

4 Recommendations for Future Research ..................................................................... 32

4.1 Expansion of Current Prototypes .................................................................... 32

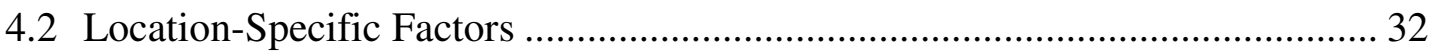

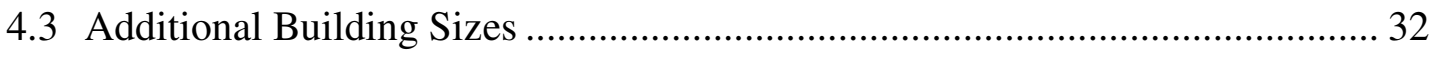

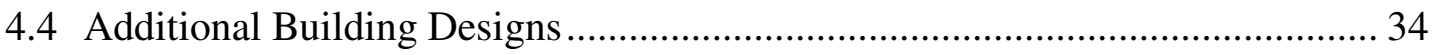




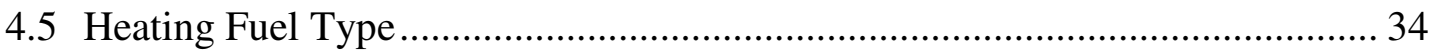

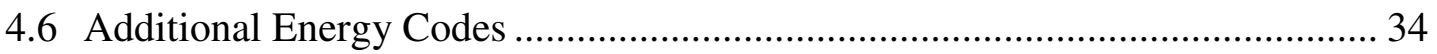

4.7 Parametric Designs beyond Current Code ………………................................ 35

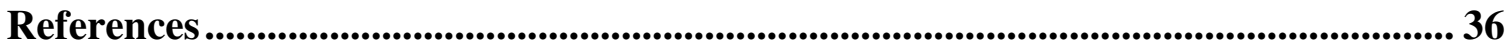

Appendix ................................................................................................................................ 38

\section{List of Figures}

Figure 2-1 Building material layers for exterior wall ..................................................... 5

Figure 2-2 Building material layers for ceiling........................................................... 6

Figure 2-3 Building material layers for roof.............................................................. 6

Figure 2-4 Building material layers for slab-on-grade .............................................. 7

Figure 2-5 Domestic Hot Water Load Profiles as a Proportion of Peak Flow Rate, By

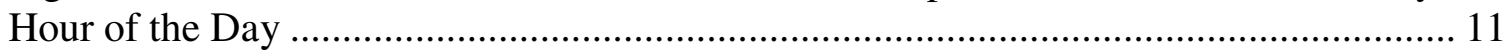

Figure 2-6 Electrical Equipment Load Profiles as a Proportion of Peak Wattage, By Hour

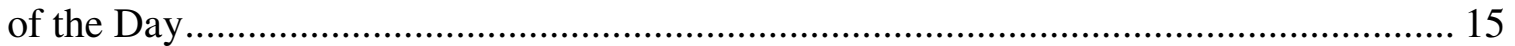

Figure 3-1 Building material layers for exterior wall ................................................... 19

Figure 3-2 Building material layers for ceiling ............................................................ 20

Figure 3-3 Building material layers for roof............................................................... 20

Figure 3-4 Building material layers for slab-on-grade ………………………………... 21

Figure 3-5 Domestic Hot Water Load Profiles as a Proportion of Peak Flow Rate, By Hour of the Day .................................................................................................... 25

Figure 3-6 Domestic Hot Water Load Profiles as a Proportion of Peak Use, By Hour of

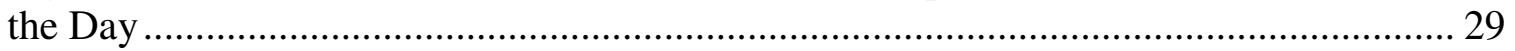

Figure 4-1 Square footage of new 1-story single-family housing ……………………... 33

Figure 4-2 Square footage of new 2-story single-family housing …………………........ 34

Figure 1 ASHRAE 90.1 Climate Zones by County .......................................................... 38

\section{List of Tables}

Table 2-1 Material Parameter Calculation Approach ........................................................ 4

Table 2-2 2009 IECC energy code requirements for exterior envelope ............................. 8

Table 2-3 Hot Water Consumption........................................................................... 10

Table 2-4 Domestic Hot Water Daily Internal Heat Gains............................................... 12

Table 2-5 Annual Lighting Electricity Consumption ...................................................... 13

Table 2-6 Lighting Load Profile as Proportion of Peak Wattage in Use, by Hour of the

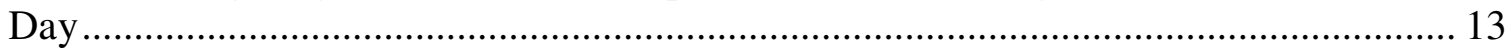

Table 2-7 Appliance and MEL Electricity Consumption ............................................... 14

Table 2-8 Occupancy Load Profile as a Proportion of Maximum Occupancy, and Total Occupants, By Hour of the Day ............................................................................... 16

Table 2-9 Heat Gain Comparison-Reference and Prototype Designs .............................. 17

Table 3-1 Material Parameter Calculation Approach …………......................................... 18

Table 3-2 2009 IECC energy code requirements for exterior envelope ........................... 22

Table 3-3 Hot Water Consumption............................................................................. 24

Table 3-4 Domestic Hot Water Internal Heat Gains....................................................... 26 
Table 3-5 Annual Lighting Electricity Consumption

Table 3-6 Lighting Load Profiles as a Proportion of Peak Wattage in Use, By Hour of the

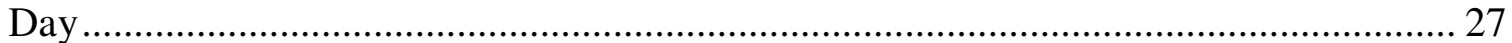

Table 3-7 Appliance and MEL Electricity Consumption ........................................... 28

Table 3-8 Occupancy Load Profile as a Proportion of Maximum Occupancy, By Hour of

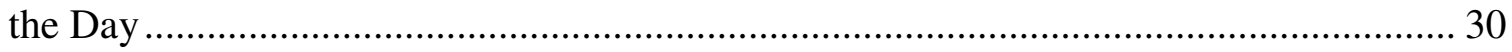

Table 3-9 Heat Gain Comparison-Reference and Prototype Designs ........................... 31

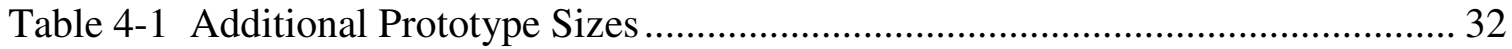

Table 4-2 Size Distribution of New Housing in Square Footage .................................. 33 


\section{List of Acronyms}

\begin{tabular}{|c|c|}
\hline AFUE & Annual Fuel Utilization Efficiency \\
\hline AHS & American Housing Survey \\
\hline ASHRAE & American Society of Heating, Refrigerating and Air-Conditioning Engineers \\
\hline $\mathrm{BA}$ & Building America \\
\hline CBECS & Commercial Building Energy Consumption Survey \\
\hline CFA & Conditioned Floor Area \\
\hline $\mathrm{COP}$ & Coefficient of Performance \\
\hline DHW & Domestic Hot Water \\
\hline DOE & Department of Energy \\
\hline EIA & Energy Information Administration \\
\hline EL & Engineering Laboaratory \\
\hline ELA & Effective Leakage Area \\
\hline EPS & Expanded Polystyrene \\
\hline HVAC & Heating, Ventilating, and Air Conditioning \\
\hline ICC & International Code Council \\
\hline IECC & International Energy Conservation Code \\
\hline IRC & International Residential Code \\
\hline MEL & Miscellanous Electric Load \\
\hline $\mathrm{N}_{\mathrm{BR}}$ & number of bedrooms \\
\hline NAHB & National Association of Home Builders \\
\hline NIST & National Institute of Standards and Technology \\
\hline NREL & National Renewable Energy Laboratory \\
\hline OAE & Office of Applied Economics \\
\hline PNNL & Pacific Northwest National Laboratory \\
\hline RECS & Residential Energy Consumption Survey \\
\hline SEER & Seasonal Energy Efficiency Ratio \\
\hline SF & Square Feet \\
\hline SHGC & Solar Heat Gain Coefficient \\
\hline SLA & Specific Leakage Area \\
\hline VT & Visible Transmittance \\
\hline XPS & Extruded Polystyrene \\
\hline
\end{tabular}




\section{Introduction}

\subsection{Background}

Previous research on residential building energy efficiency has created energy modeling parameters for predicting energy use for both new and existing residential buildings. These studies specify a majority of the parameters required to create a residential building energy simulation model, which are useful when the building design is known. However, prototype residential building designs that represent "typical" residential buildings are required to consistently analyze energy efficiency improvements across the U.S. building stock.

\subsection{Purpose}

The purpose of this report is twofold. First, it develops and documents prototype residential building designs. These prototype designs provide a consistent basis for running building energy simulations across the U.S. residential building stock for different climate zones and varying levels of energy efficiency. Second, this report can be used as a basis for adding more prototype building designs or for developing more detailed designs of the prototypes reported here.

\subsection{Literature Review}

Previous research on prototype building designs has focused on commercial buildings. The National Renewable Energy Laboratory (NREL) has documented 16 commercial prototypical buildings for 16 U.S. climate zones. ${ }^{1}$ These 256 reference commercial buildings are based on the Commercial Building Energy Consumption Survey (CBECS) database and the American Society of Heating, Refrigerating and Air-Conditioning Engineers (ASHRAE) 90.1 Standard, and represent greater than $70 \%$ of the U.S. building stock. These prototypes have become the basis for significant research on energy efficiency measures in commercial buildings.

Two reports from the Building America (BA) program of the DOE Building Technologies Program -- Hendron and Engebrecht (2010) and Hendron (2006) -document the assumptions for energy efficiency performance comparison for new and existing residential buildings, respectively. These reports define total loads and load profiles for energy and water usage within a home based on the number of bedrooms, bathrooms, and square footage. Since the focus of this study is on new residential buildings, Hendron and Engebrecht (2010) will be a primary source of information for the prototype designs.

${ }^{1}$ Field, Deru, and Studer (2010) 
Persily et al. (2007) define a suite of over 200 homes that represent approximately $80 \%$ of the U.S. housing stock, including detached, attached, manufactured, and apartment buildings for use in indoor air quality research. The prototypes are based on the Residential Energy Consumption Survey (RECS) and American Housing Survey (AHS) databases. The study defines the conditioned floor area (CFA) and dimensions of 3 different detached homes: $107.0 \mathrm{~m}^{2}\left(1152 \mathrm{ft}^{2}\right), 180.4 \mathrm{~m}^{2}\left(1942 \mathrm{ft}^{2}\right)$, and $275.5 \mathrm{~m}^{2}$ $\left(2966 \mathrm{ft}^{2}\right)^{2}$

Pacific Northwest National Laboratory (PNNL) published a report for the DOE Building Energy Codes Program that analyzes the state-level impacts of the adoption of 2009 IECC for residential buildings. ${ }^{3}$ The study uses EnergyGauge (based on the DOE-2 whole building energy simulation software) to determine the energy use and cost savings for a two-story, $223 \mathrm{~m}^{2}\left(2400 \mathrm{ft}^{2}\right)$ house. ${ }^{4}$

The literature has not yet documented the details of the assumptions made in designing prototype residential buildings. This report will document the assumptions for two such prototypes to be used for simulating energy use and measuring sustainability in detached homes.

\subsection{Approach}

Prototype residential building designs are based on a number of sources, including the research described above by Building America. Additional resources are RS Means cost databases, U.S. Census and EIA housing stock data, and a collection of ASHRAE standards and IECC codes. The prototype buildings are designed in the EnergyPlus V6.0 simulation software. ${ }^{5}$

Two prototypical residential building designs are documented in this report: one-story and two-story detached homes. The framework for these designs is the 2009 IECC Residential Code for One- and Two-Story Dwellings. IECC code defines the thermostat control, window specifications, exterior envelope R-values $\left(\mathrm{m}^{2}-\mathrm{K} / \mathrm{W}\right)$, minimum lighting efficiency, maximum infiltration rates, mechanical ventilation, internal and structural mass, and heating, ventilating, and air-conditioning (HVAC) system requirements.

\footnotetext{
${ }^{2}$ Persily et al. (2007) does not create 3-dimensional representations of the prototypical homes because it was not required for their analysis.

${ }^{3}$ PNNL (2009)

${ }^{4}$ The report does not specify the reasoning behind the building design selection.

${ }^{5}$ Department of Energy (2010)
} 
Although 2009 IECC defines the general framework for modeling, the code does not address the building's plug loads, occupancy, or geometry. Also lacking is a number of small, but important details and assumptions required to effectively simulate the energy use of a residential building.

One source of this additional information is the Building America Research Benchmark Definition (2010), which is used for the annual loads, load profiles, and internal heat gains for lighting, occupancy, and domestic hot water.

Prototypical building size and geometry are selected based on four sources. The American Housing Survey (AHS) and the EIA Residential Energy Consumption Survey (RECS) are used to determine typical square footage and number of bedrooms for onestory and two-story residential detached buildings. The Annual 2010 Characteristics of New Housing released by the U.S. Census Bureau's Manufacturing, Mining, and Construction Statistics Division (MCD) and RSMeans Square Foot Costs (2011) are used to determine appropriate prototype building geometries. Selections are comparable to Persily et al. (2007).

Other codes and standards are needed to establish additional specifications: International Residential Code (IRC), ASHRAE 90.2-2007, ASHRAE 62.2-2010, and the ASHRAE Fundamentals Handbook. Their use will be defined in detail where appropriate in the remainder of the document. 


\section{One-Story Building Design Specification}

The first building design represents a typical 1-story, 3-bedroom, slab-on-grade detached house with no garage. This design was chosen because it is the simplest building design and can be used as the framework for more detailed single-story house designs. In the remainder of this section, each aspect of the building design and operation will be defined.

\subsection{Building Envelope}

There are some building envelope assumptions that are constant regardless of the building location's climate while other assumptions are climate specific. The following two subsections will define each set of assumptions separately.

\subsubsection{General Assumptions}

The prototype is a 2009 IECC compliant 1-story 3-bedroom slab-on-grade house. The dimensions are $19.5 \mathrm{~m} \mathrm{x} 7.6 \mathrm{~m}(64 \mathrm{ft} \times 25 \mathrm{ft})$ for a total of $148.6 \mathrm{~m}^{2}\left(1,600 \mathrm{ft}^{2}\right)$ of conditioned floor area (CFA). The house is oriented $19.5 \mathrm{~m}(64 \mathrm{ft})$ east to west and $7.6 \mathrm{~m}$ $(25 \mathrm{ft})$ north to south. The first floor has a $2.4 \mathrm{~m}(8 \mathrm{ft})$ high ceiling. The roof slope is assumed to be $4: 12$ with $0.3 \mathrm{~m}$ (1ft) overhangs on the north and south sides of the building. There is assumed to be no garage in the prototype.

The house is built to meet 2009 IECC for low-rise residential buildings. The EnergyPlus parameters for the materials used in the exterior envelope (excluding the roof) are estimated using an average transmittance with the surface-weighted path fractions. In other words, using a simple weighted average of parameter values based on the percentage of framing in the surface. The roof controls for varying materials by splitting the roof into two separate surfaces. The framing percentage for each surface type is shown in Table 2-1.

\section{Table 2-1 Material Parameter Calculation Approach}

\begin{tabular}{lcc} 
Construction & Pct. Frame & Approach \\
\hline Exterior Wall & $23 \%$ & surface-weighted path fractions \\
Ceiling & $11 \%$ & surface-weighted path fractions \\
Roof & $11 \%$ & split into separate surfaces
\end{tabular}

The exterior wall is assumed to be $3.8 \mathrm{~cm} \mathrm{x} 8.9 \mathrm{~cm}(1.5$ in x 3.5 in) wood-framed $41 \mathrm{~cm}$ (16 in) on center (OC) with cavity insulation $(9 \mathrm{~cm}$ (3.42 in) fiberglass batts at $0.67 \mathrm{~m}^{2} \cdot \mathrm{K} / \mathrm{W}\left(\mathrm{R}-3.8 \mathrm{ft}^{2} \cdot{ }^{0} \mathrm{~F} \cdot \mathrm{h} / \mathrm{Btu}\right)$ per $2.5 \mathrm{~cm}(1 \mathrm{in})$. The material layers for the exterior 
wall are defined in Figure 2-1. The construction is made of 5 or 6 layers depending on IECC requirements: wood siding, a felt air barrier, rigid insulation (if required), plywood sheathing, $3.8 \mathrm{~cm} \times 8.9 \mathrm{~cm}$ (1.5 in x 3.5 in) framing with batt insulation in wall cavity, and gypsum wall board (GWB).

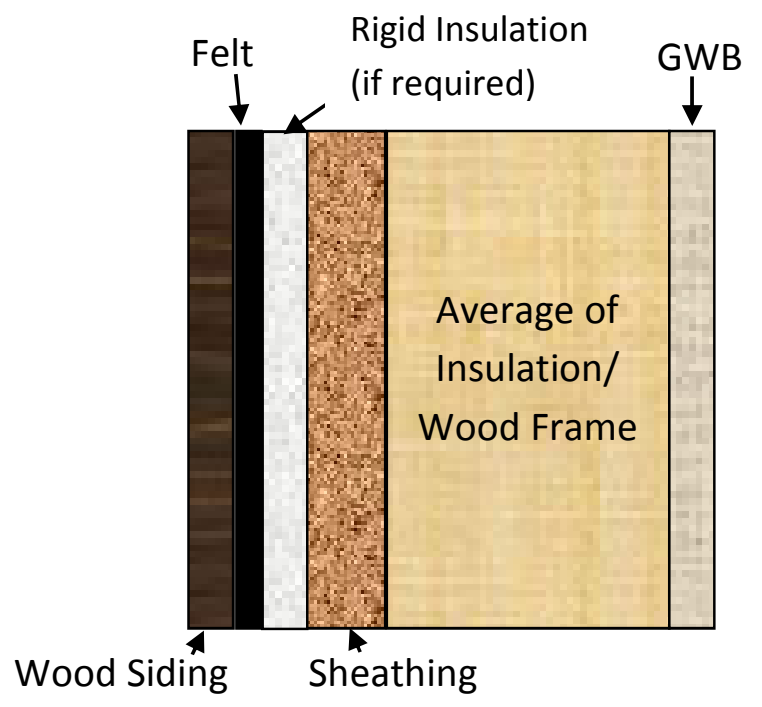

Figure 2-1 Building material layers for exterior wall

The average conductance (U-factor) of the framing/insulation combination material is calculated by the following equation from ASHRAE Fundamentals Handbook (2009):

$$
U_{A V G}=23 \% * U_{\text {FRAME }}+77 \% * U_{\text {INSULATION }}
$$

For this material, $23 \%$ of the wall area is framing with the remaining $77 \%$ being the wall cavity that is filled with cavity insulation.

The interior ceiling is assumed to be $1.3 \mathrm{~cm}(0.5 \mathrm{in}) \mathrm{GWB}$ with $3.8 \mathrm{~cm} \times 14.0 \mathrm{~cm}(1.5 \mathrm{in}$ $x 5.5$ in) ceiling joists. There is blown-in cellulose insulation in the open cavity plus any additional inches of blown-in insulation as required by 2009 IECC. The amount of blown-in insulation varies by climate zone, and will be described in Section 2.1.2. The average material $\mathrm{U}$-factor is calculated in the same manner as the exterior wall for the wood frame/cavity layer. Framing accounts for $11 \%$ of the ceiling surface. The material layers for the ceiling are defined in Figure 2-2. 


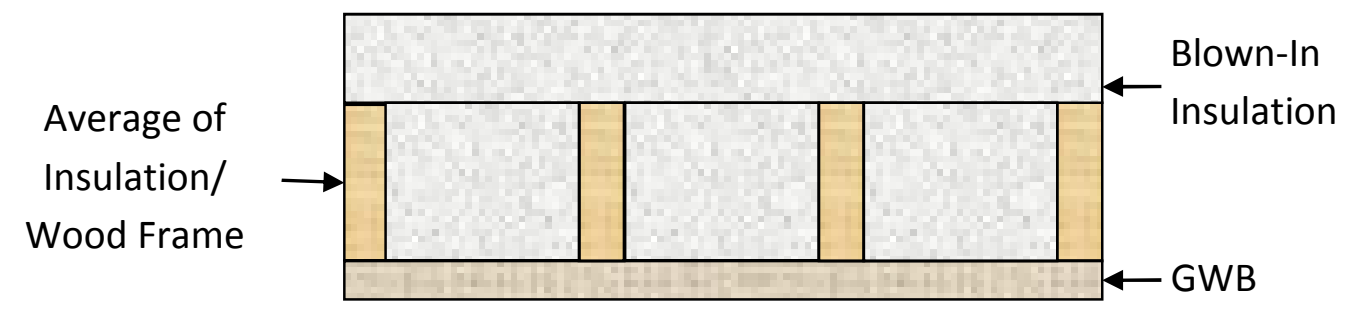

Figure 2-2 Building material layers for ceiling

The roof construction is assumed to be $3.8 \mathrm{~cm} \times 14.0 \mathrm{~cm}$ ( $1.5 \mathrm{in} \mathrm{x} 5.5$ in) rafters with $1.3 \mathrm{~cm}(0.5 \mathrm{in})$ plywood sheathing, felt paper, and asphalt shingles. There is no insulation in the rafters, which makes it unnecessary to calculate an average U-factor. Instead the roof is split into two surfaces for energy simulation, one with framing ( $23 \%$ of roof area) and one without framing (77\% of roof area). The material layers for the roof with framing are defined in Figure 2-3.

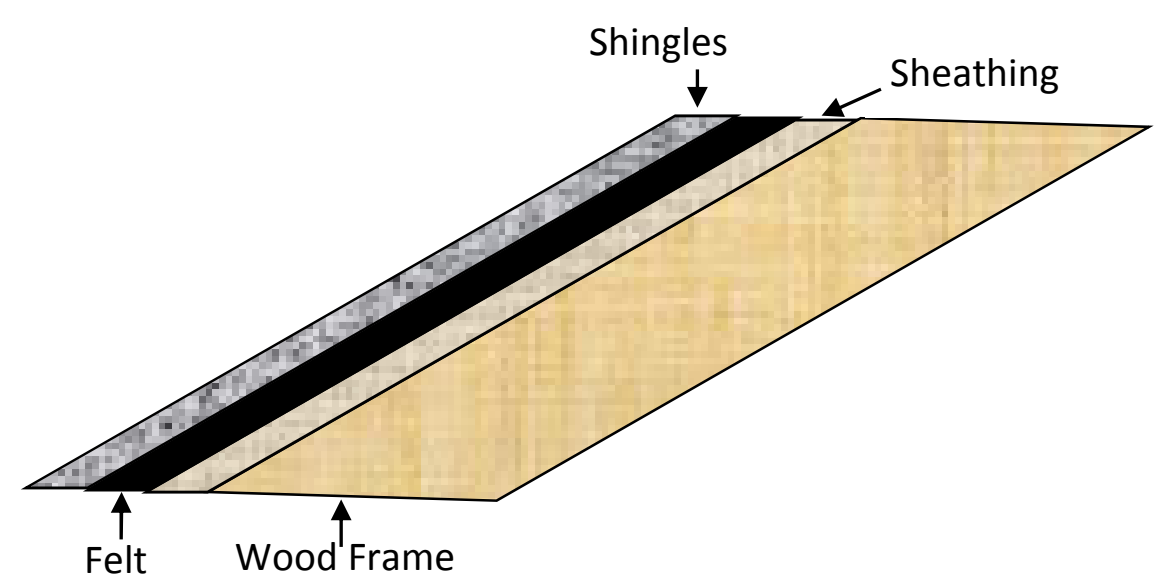

Figure 2-3 Building material layers for roof

The foundation is a $10 \mathrm{~cm}$ ( 4 in) concrete slab. The floor finish is assumed to be $40 \%$ carpet, $40 \%$ hardwood, $15 \%$ vinyl tile, and $5 \%$ ceramic tile (based on RSMeans Square Foot Costs). Some climate zones require rigid insulation to be placed on the slab edge, which will be described in Section 2.1.2. The material layers for the slab are defined in Figure 2-4. The EnergyPlus Slab preprocessor is used to simulate the heat transfer between the ground and the slab, which recommends simulating horizontal insulation under the slab instead of vertical insulation on the edge of the slab for "slab-on-grade" foundations because the energy transfer that occurs on the vertical edges of the slab are significantly smaller than the energy transfer from the surface area contacting the ground. The Slab preprocessor assumes that the bottom of the slab is flush with the grade. 


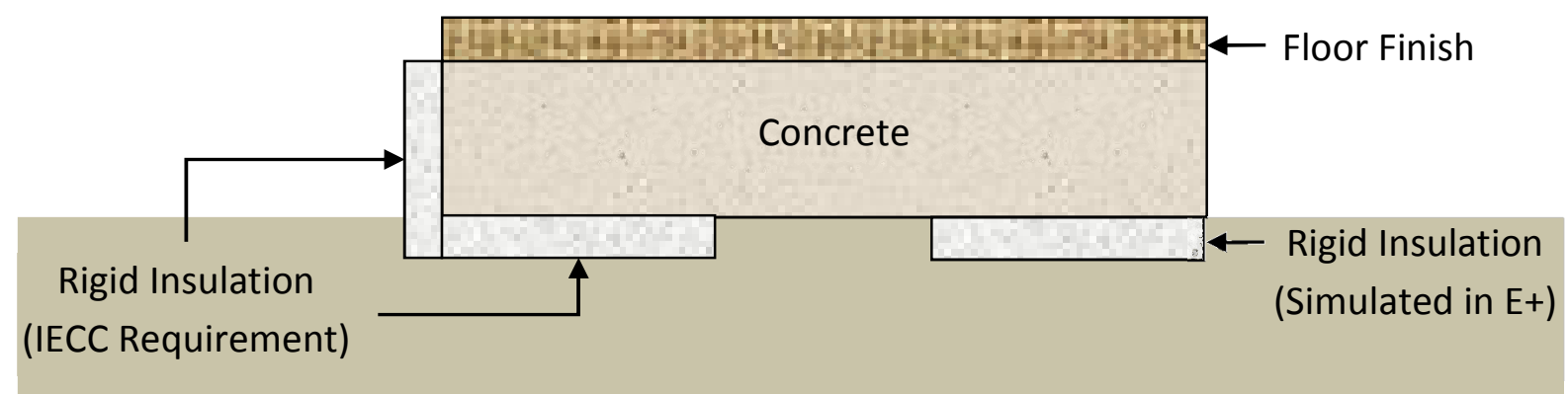

Figure 2-4 Building material layers for slab-on-grade

Window glazing area is assumed to be $15 \%$ of conditioned floor area and is split between the four exterior walls based on wall area. Two $1.2 \mathrm{~m}(4 \mathrm{ft})$ high windows on each side of the house ( 8 in total) are assumed to be located equal distance from the wall edge. The width of the windows is based on the fraction of total wall area represented by each side. There are assumed to be two $0.9 \mathrm{~m} \times 2.0 \mathrm{~m}$ ( $3 \mathrm{ft} \times 6 \mathrm{ft} 8 \mathrm{in})-4.4 \mathrm{~cm}(1.75 \mathrm{in})$ solid pine wood doors, located in the center of the wall on the north and south walls. Windows are defined in EnergyPlus using the "Simple Glazing System," which requires only 3 parameters: $\mathrm{U}$-factor $\left(\mathrm{W} /\left(\mathrm{m}^{2} \cdot \mathrm{K}\right)\right)$, solar heat gain coefficient (SHGC), and visible transmittance (VT). These parameters vary by climate zone, and will be described in Section 2.1.2.

\subsubsection{Climate Zone-Specific Assumptions}

The exterior envelope performance requirements of 2009 IECC vary depending on the climate zone. Table 2-2 is an abridged version of Table 402.1.1 found in Chapter 4: Residential Energy Efficiency of the 2009 IECC. A map of the climate zones by county is found in the appendix. 
Table 2-2 2009 IECC energy code requirements for exterior envelope

\begin{tabular}{|c|c|c|c|c|c|c|}
\hline Climate Zone & $\begin{array}{c}\text { Fenestration } \\
\text { U-Factor } \\
\left(\mathbf{W} / \mathbf{m}^{2} \cdot \mathbf{K}\right)\end{array}$ & $\begin{array}{c}\text { Glazed } \\
\text { Fenestration } \\
\text { SHGC }\end{array}$ & $\begin{array}{l}\text { Ceiling } \\
\text { R-Value }\end{array}$ & Wood Frame Wall R-Value & $\begin{array}{l}\text { Slab Edge } \\
\text { R-Value }\end{array}$ & Slab Depth \\
\hline 1 & 1.2 & 0.30 & $5.3(30)$ & $2.3(13)$ & $0(0)$ & $0(0)$ \\
\hline 2 & 0.65 & 0.30 & $5.3(30)$ & $2.3(13)$ & $0(0)$ & $0(0)$ \\
\hline 3 & 0.50 & 0.30 & $5.3(30)$ & $2.3(13)$ & $0(0)$ & $0(0)$ \\
\hline 4 except Marine & 0.35 & $\mathrm{NR}^{*}$ & $6.7(38)$ & $2.3(13)$ & $1.8(10)$ & $0.61 \mathrm{~m}(2 \mathrm{ft})$ \\
\hline 5 and 4 Marine & 0.35 & NR* & $6.7(38)$ & $3.5(20)$ or $2.3+0.88(13+5)^{* *}$ & $1.8(10)$ & $0.61 \mathrm{~m}(2 \mathrm{ft})$ \\
\hline 6 & 0.35 & $\mathrm{NR}^{*}$ & $8.6(49)$ & $3.5(20)$ or $2.3+0.88(13+5)^{* *}$ & $1.8(10)$ & $1.21 \mathrm{~m}(4 \mathrm{ft})$ \\
\hline 7 and 8 & 0.35 & $\mathrm{NR}^{*}$ & $8.6(49)$ & $3.7(21)$ & $1.8(10)$ & $1.21 \mathrm{~m}(4 \mathrm{ft})$ \\
\hline
\end{tabular}

Although EnergyPlus requires three parameters for defining window performance, 2009 IECC only specifies two: U-factor and SHGC. The U-factor is restricted to below 1.2 in Zone 1 and becomes stricter the colder the climate zone, restricting the U-factor to below 0.35 in Zones 7 and 8 . The SHGC must be less than 0.30 for Zones 1 through 3, but has no requirement for Zones 4 through 8 . The SHGC for the standard reference design specified in 2009 IECC is 0.40 for Zones 4 through 8 . The visible transmittance is not restricted in 2009 IECC for any climate zones, and is assumed to be 0.16 for Zone $1,0.22$ for Zone 2, 0.46 for Zone 3, and 0.40 for Zones 4 through $8 .^{6}$

The insulation R-values for the exterior walls, ceiling, and foundation increase as the climate zone gets colder. The exterior wall R-value ranges from R-13 in Zones 1 through 4 to R-21 in Zones 7 and 8 . The first R-13 is met with high density cavity insulation in the wall cavity. Additional $R$-value is met by adding rigid insulation to the exterior of the wall. The ceiling R-value ranges from R-30 in Zones 1 through 3 to R-49 in Zones 6 through 8. Additional cellulose blown-in insulation is used to reach the required R-value. R-10 insulation under the foundation is required in Zones 4 through 8 only, which is met by adding 2 in of extruded polystyrene (XPS) below the slab.

\footnotetext{
${ }^{6}$ Visible transmittance values are based on window characteristics defined in the ASHRAE Fundamentals Handbook (2009).
} 


\subsection{Heating, Ventilating, and Air Conditioning Equipment}

The HVAC system in the prototype building design is a single-speed unitary system with an air conditioner with a Seasonal Energy Efficiency Ratio (SEER) rating of $13,{ }^{7}$ and a gas furnace with annual fuel utilization efficiency (AFUE) of $78 \%$ (both current minimum federal energy efficiency requirements). No dehumidification option or economizer is included in the system. The supply fan is assumed to cycle, and has a total efficiency of $70 \%$. The supply fan motor efficiency is $90 \%$. The ductwork is assumed to be within the conditioned space, which leads to zero energy loss from the ductwork. This assumption assists in simplifying the model, and will be relaxed in future research to account for split systems and the resulting duct leakage. ${ }^{8}$

\subsection{Operating Conditions}

The thermostat setpoints are based on the standard reference designs defined in 2009 IECC, which are $23.9^{\circ} \mathrm{C}\left(75^{\circ} \mathrm{F}\right)$ cooling and $22.2^{\circ} \mathrm{C}\left(72^{\circ} \mathrm{F}\right)$ heating.

\subsection{Mechanical Ventilation and Air Infiltration}

The mechanical ventilation rate is based on ASHRAE Standard 62.2-2010. The Minimum Outdoor Air Flow Rate (liters per second) is based on ASHRAE 62.2-2010 equation 4.1b:

$$
0.05 * m^{2}+3.5 *\left(N_{B R}+1\right)
$$

For the prototype design's $148.6 \mathrm{~m}^{2}\left(1600 \mathrm{ft}^{2}\right)$ and 3 bedrooms, the total house ventilation rate is $0.02162 \mathrm{~m}^{3}$ per second ( $46 \mathrm{ft}^{3}$ per minute). The ASHRAE 62.2-2010 requirements have a built-in $0.15 \mathrm{ACH}$ of air leakage. Door infiltration is assumed to be included in the $\mathrm{ACH}^{9}$

The prescriptive maximum air leakage of 7 air changes per hour (ACH) at 50 pascals specified in Section 402.4.2.1 of the 2009 IECC is not defined under normal operating conditions. For this reason, leakage is based on ASHRAE 62.2-2010.

Table 405.5.2(1) of the 2009 IECC specifies that "residences with mechanical ventilation that are test in accordance with ASHRAE 119, Section 5.1, the measured air exchange rate combined with the mechanical ventilation rate...shall not be less than" the ASHRAE

\footnotetext{
${ }^{7}$ The 13 SEER rating converts to a Coefficient of Performance (COP) of 3.28 for the EnergyPlus simulation based on the following equation: $C O P=\left(-0.02 * S E E R^{2}+1.12 * S E E R\right) / 3.412$.

${ }^{8}$ The 2009 IECC prescriptive requirements include a duct tightness post-construction test showing duct leakage less than or equal to $226.5 \mathrm{~L} / \mathrm{min}(8 \mathrm{CFM})$ per $9.29 \mathrm{~m}^{2}\left(100 \mathrm{ft}^{2}\right)$ at $25 \mathrm{Pascal}(\mathrm{Pa})$.

${ }^{9}$ According to the ASHRAE Fundamentals Handbook, "In residences...air exchange associated with a door can be estimated based on air leakage through cracks between door and frame.
} 
62.2-2010 minimum outdoor air flow rate. As assumed in ASHRAE 62.2-2010, the air infiltration rate is assumed to be $0.15 \mathrm{ACH}$.

The standard reference design in 2009 IECC assumes the attic is vented with venting equivalent to 1 unit per 300 units of the ceiling area, which converts to an effective leakage area (ELA) of $4954.8 \mathrm{~cm}^{2}\left(5.33 \mathrm{ft}^{2}\right)$.

\subsection{Domestic Hot Water}

The BA Benchmark functions defined in Table 2-3 are used instead of 2009 IECC to estimate the hot water consumption of each piece of equipment and activities. Total hot water consumption based on the BA Benchmark is 303 liters ( 80 gallons). These estimates are used for the analysis because they break down consumption by end use; the 2009 IECC estimate is for total hot water consumption only. The clothes washer and dishwasher use only hot water $48.9^{\circ} \mathrm{C}\left(120^{\circ} \mathrm{F}\right)$ while the showers, baths, and sinks use hot water that is tempered to $40.6^{\circ} \mathrm{C}\left(105^{\circ} \mathrm{F}\right)$, as shown in Table 2-3. Since some of the water consumed is tempered with cold water, the total hot water drawn from the hot water tank is 273 liters (72.5 gallons) per day.

\section{Table 2-3 Hot Water Consumption}

\begin{tabular}{lccc}
\multicolumn{1}{c}{ Equipment } & Water Temp. & $\begin{array}{c}\text { Function } \\
\text { Liters (Gallons) }\end{array}$ & $\begin{array}{c}\text { Liters (Gallons) } \\
\text { Per Day }\end{array}$ \\
\hline Clothes Washer & $48.9^{\circ} \mathrm{C}\left(120^{\circ} \mathrm{F}\right)$ & $28+10^{*} \mathrm{~N}_{\mathrm{BR}}\left(7.5+2.5^{*} \mathrm{~N}_{\mathrm{BR}}\right)$ & $56.8(15)$ \\
Dishwasher & $48.9^{\circ} \mathrm{C}\left(120^{\circ} \mathrm{F}\right)$ & $10+3^{*} \mathrm{~N}_{\mathrm{BR}}\left(2.5+0.833^{*} \mathrm{~N}_{\mathrm{BR}}\right)$ & $18.9(5)$ \\
Showers & $40.6^{\circ} \mathrm{C}\left(105^{\circ} \mathrm{F}\right)$ & $53+18^{*} \mathrm{~N}_{\mathrm{BR}}\left(14.0+4.67 * \mathrm{~N}_{\mathrm{BR}}\right)$ & $106.0(28)$ \\
Baths & $40.6^{\circ} \mathrm{C}\left(105^{\circ} \mathrm{F}\right)$ & $13+4 * \mathrm{~N}_{\mathrm{BR}}\left(3.5+1.17 * \mathrm{~N}_{\mathrm{BR}}\right)$ & $26.5(7)$ \\
Sinks & $40.6^{\circ} \mathrm{C}\left(105^{\circ} \mathrm{F}\right)$ & $47+16^{*} \mathrm{~N}_{\mathrm{BR}}\left(12.5+4.16^{*} \mathrm{~N}_{\mathrm{BR}}\right)$ & $94.6(25)$ \\
& & & Total: \\
& & & $303(80)$ \\
\hline
\end{tabular}

The BA Benchmark total water use, daily water use load profiles, and sensible (temperature-based) and latent (humidity-based) loads for hot water use are used to estimate the real time hot water use and the resulting internal heat gains. The daily load profile, or proportion of peak flow rate by hour of the day, for each hot water use category can be seen in Figure 2-5. 

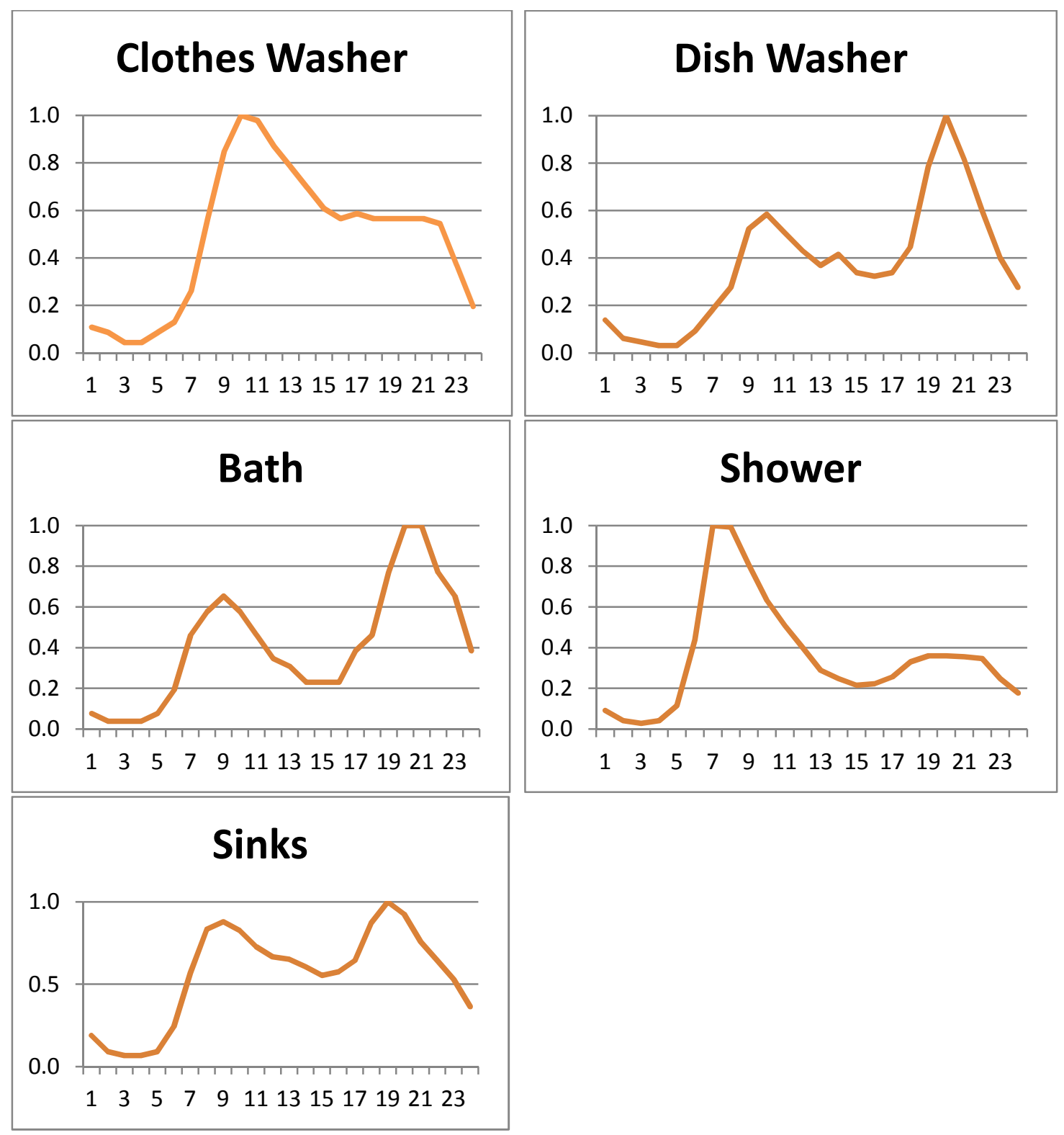

Figure 2-5 Domestic Hot Water Load Profiles as a Proportion of Peak Flow Rate, By Hour of the Day

Internal heat gains from hot water for the clothes washer and dishwasher are assumed to be zero for both sensible and latent loads. Any heat gains for this equipment are included in the equipment electricity use heat gains. The sensible and latent load fractions for shower, bath, and sinks are reverse engineered from internal heat gains estimated using the BA Benchmark functions in Table 2-4. 
Table 2-4 Domestic Hot Water Daily Internal Heat Gains

\begin{tabular}{|l|c|c|c|c|c|c|}
\hline \multirow{2}{*}{$\begin{array}{c}\text { Equipment } \\
\text { End Use }\end{array}$} & \multicolumn{3}{|c|}{ Sensible Load } & \multicolumn{3}{c|}{ Latent } \\
\cline { 2 - 7 } & $\begin{array}{c}\text { Function } \\
\text { kWh (Btu) }\end{array}$ & $\begin{array}{c}\text { Heat Gain } \\
\text { kWh (Btu) }\end{array}$ & $\begin{array}{c}\text { Load } \\
\text { Fraction }\end{array}$ & $\begin{array}{c}\text { Function } \\
\text { kWh (Btu) }\end{array}$ & $\begin{array}{c}\text { Heat Gain } \\
\text { kWh (Btu) }\end{array}$ & $\begin{array}{c}\text { Load } \\
\text { Fraction }\end{array}$ \\
\hline Showers & $\begin{array}{c}0.22+0.07 * \mathrm{~N}_{\mathrm{BR}} \\
\left(741+247 * \mathrm{~N}_{\mathrm{BR}}\right)\end{array}$ & $0.4(1482)$ & 0.1947 & $\begin{array}{c}0.21+0.07 * \mathrm{~N}_{\mathrm{BR}} \\
\left(703+235 * \mathrm{~N}_{\mathrm{BR}}\right)\end{array}$ & $0.4(1408)$ & 0.0055 \\
\hline Baths & $0.05+0.02 * \mathrm{~N}_{\mathrm{BR}}$ & $0.4(1371)$ & 0.7262 & $0(0)$ & $0(0)$ & 0.0000 \\
\hline Sinks & $\left(185+62 * \mathrm{~N}_{\mathrm{BR}}\right)$ & & & & & \\
\hline & $0.09+0.03 * \mathrm{~N}_{\mathrm{BR}}$ & $0.2(619)$ & 0.0917 & $\begin{array}{c}0.04+0.01 * \mathrm{~N}_{\mathrm{BR}} \\
\left(140+47 * \mathrm{~N}_{\mathrm{BR}}\right)\end{array}$ & $0.1(281)$ & 0.0012 \\
\hline
\end{tabular}

Based on 2009 IECC, the water heater must meet federal energy efficiency requirements. The water heater is assumed to be a gas water heater with a perfectly mixed storage tank with an efficiency of $76 \%,{ }^{10}$ a firing rate of $10551 \mathrm{~W},{ }^{11}$ and a setpoint temperature of $48.9^{\circ} \mathrm{C}\left(120^{\circ} \mathrm{F}\right)$. The heat loss coefficient from the water heater to the ambient temperature in the internal space is assumed to be $2.1 \mathrm{~W} / \mathrm{K}^{12}$

\subsection{Lighting}

The lighting load profiles and electricity consumption are based on the simplest profile in the BA Benchmark, which varies by time-of-day, but not from day-to-day. Total electricity use is estimated based on the two-stage process defined in the BA Benchmark as expressed in Table 2-5. The baseline lighting estimate is based on $86 \%$ incandescent and $14 \%$ fluorescent use. The lighting requirements in 2009 IECC require $50 \%$ high efficacy lighting, which is met by using $50 \%$ compact fluorescent lamp (CFL) lighting. The BA Benchmark adjustment functions shown on the right in Table 2-5 are used to adjust the total electricity consumption estimate to represent the greater efficiency required by 2009 IECC. The baseline total lighting electricity consumption is estimated at $1918 \mathrm{kWh}$. The 2009 IECC-compliant lighting decreases lighting electricity consumption by $26 \%$ to $1415 \mathrm{kWh}$.

\footnotetext{
${ }^{10}$ Minimum federal efficiency requirement for gas water heaters

${ }^{11}$ Based on the BA Benchmark for a 3 bedroom/2 bathroom house with a gas unit

12 Based on NIST expert recommendation
} 
Table 2-5 Annual Lighting Electricity Consumption

\begin{tabular}{|l|c|r|c|r|}
\hline \multirow{2}{*}{$\begin{array}{c}\text { Lighting } \\
\text { Use } \\
\text { Category }\end{array}$} & \multicolumn{2}{|c|}{ Baseline } & \multicolumn{2}{c|}{ 2009 IECC-Compliant } \\
\cline { 2 - 5 } & Function & kWh & Function & kWh \\
\hline Hard-wired & $0.8 *(\mathrm{CFA} * 0.737+467)$ & 1317 & $1,317 *\left[\left(\mathrm{~F}_{\mathrm{INC}}+0.14\right)+\left(\mathrm{F}_{\mathrm{CFL}}-0.14\right) * 0.27\right]$ & 971 \\
\hline Plug-In & $0.2 *(\mathrm{CFA} * 0.737+467)$ & 329 & $329 *\left[\left(\mathrm{~F}_{\mathrm{INC}}+0.14\right)+\left(\mathrm{F}_{\mathrm{CFL}}-0.14\right) * 0.27\right]$ & 243 \\
\hline Exterior & CFA*0.17 & 272 & $272 *\left[\left(\mathrm{~F}_{\mathrm{INC}}+0.14\right)+\left(\mathrm{F}_{\mathrm{CFL}}-0.14\right) * 0.27\right]$ & 201 \\
\hline Total & $\mathrm{CFA} * 0.737+467+\mathrm{CFA} * 0.17$ & 1918 & $1,918 *\left[\left(F_{I N C}+0.14\right)+\left(F_{C F L}-0.14\right) * 0.27\right]$ & 1415 \\
\hline
\end{tabular}

The load profile (proportion of peak wattage in use) for interior lighting can be seen in Table 2-6. The total wattage parameter for lighting in EnergyPlus is reverse engineered from the peak consumption load profile and the total electricity consumption estimate. The load profile for exterior lighting assumes the lights are on sunset to sunrise.

Table 2-6 Lighting Load Profile as Proportion of Peak Wattage in Use, by Hour of the Day

\begin{tabular}{|c|c|}
\hline Hour & Load Profile \\
\hline $1: 00$ & 0.067 \\
\hline $2: 00$ & 0.067 \\
\hline $3: 00$ & 0.067 \\
\hline $4: 00$ & 0.067 \\
\hline $5: 00$ & 0.187 \\
\hline $6: 00$ & 0.394 \\
\hline $7: 00$ & 0.440 \\
\hline $8: 00$ & 0.393 \\
\hline $9: 00$ & 0.172 \\
\hline $10: 00$ & 0.119 \\
\hline $11: 00$ & 0.119 \\
\hline $12: 00$ & 0.119 \\
\hline
\end{tabular}

\begin{tabular}{|c|c|}
\hline Hour & Load Profile \\
\hline $13: 00$ & 0.119 \\
\hline $14: 00$ & 0.119 \\
\hline $15: 00$ & 0.119 \\
\hline $16: 00$ & 0.206 \\
\hline $17: 00$ & 0.439 \\
\hline $18: 00$ & 0.616 \\
\hline $19: 00$ & 0.829 \\
\hline $20: 00$ & 0.986 \\
\hline $21: 00$ & 1.000 \\
\hline $22: 00$ & 0.692 \\
\hline $23: 00$ & 0.384 \\
\hline $24: 00$ & 0.16 \\
\hline
\end{tabular}




\subsection{Appliances and Miscellaneous Electrical Loads}

The electrical equipment in the house includes a refrigerator, clothes washer, clothes dryer, dishwasher, electric range, and a combination of variable miscellaneous electrical loads (MELs). MELs encompass electronics such as computers, televisions, stereos, and other plug loads. The electricity consumption for each category is based on the BA Benchmark functions seen in Table 2-7. Electricity consumption is usually a function of the number of bedrooms in the home $\left(\mathrm{N}_{\mathrm{BR}}\right)$.

Table 2-7 Appliance and MEL Electricity Consumption

\begin{tabular}{|c|c|c|}
\hline Equipment & Function & kWh \\
\hline Refrigerator & Constant & 669 \\
\hline Clothes Washer & $52.5+17.5 * \mathrm{~N}_{\mathrm{BR}}$ & 105 \\
\hline Clothes Dryer & $418+139 * N_{B R}$ & 835 \\
\hline Dishwasher & $103+34.3 * \mathrm{~N}_{\mathrm{BR}}$ & 206 \\
\hline Electric Range & $302+101 * \mathrm{~N}_{\mathrm{BR}}$ & 605 \\
\hline Variable MELs & $1281+\left(196 * \mathrm{~N}_{\mathrm{BR}}\right)+(0.345 * \mathrm{CFA})$ & 2421 \\
\hline & Total: & 4841 \\
\hline
\end{tabular}

The BA Benchmark load profiles in Figure 2-6 create a real-time variation in electricity consumption for each category. Appliances such as the electric range and dishwasher have a significant variation in time-of-day use while refrigerator use only varies slightly over a day. 


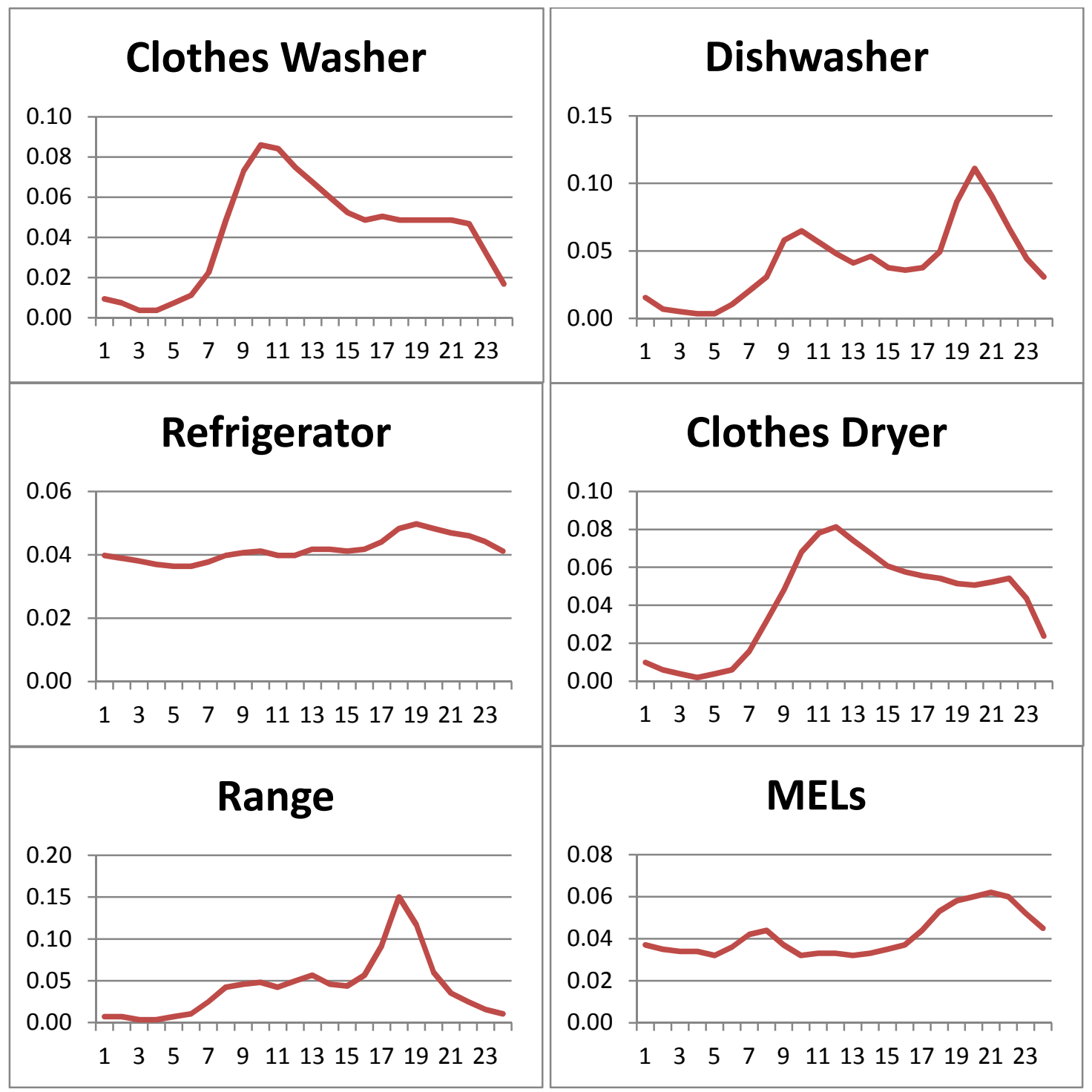

Figure 2-6 Electrical Equipment Load Profiles as a Proportion of Peak Wattage, By Hour of the Day

\subsection{Internal Mass}

Instead of defining individual interior surfaces and furniture, internal mass is estimated based on ASHRAE 90.2-2007 recommendations. There is assumed to be $3.6 \mathrm{~kg}$ (8 lb) of $5 \mathrm{~cm}$ ( 2 in) thick wood per square foot of conditioned space for contents for a total of $5806 \mathrm{~kg}(12800 \mathrm{lb})$. There is assumed to be $2.3 \mathrm{~kg}(5 \mathrm{lb})$ of $1.3 \mathrm{~cm}(0.5 \mathrm{in})$ gypsum wall board $(\mathrm{GWB})$ per square foot of conditioned space for the internal structure for a total of $3629 \mathrm{~kg}(8000 \mathrm{lb})$.

EnergyPlus estimates internal mass in terms of square meters of material open to the zone air. Based on the total weight of the two materials (wood and GWB) and their weight per 
inch, it is possible to determine the comparable surface area needed to match the amount of internal mass required. Assuming the wood density is equivalent to that of white oak, $753 \mathrm{~kg} \mathrm{per} \mathrm{m}^{3}\left(47 \mathrm{lb}\right.$ per ft $\left.^{3}\right)$, the $5 \mathrm{~cm}\left(2\right.$ in) thick wood weighs $38 \mathrm{~kg} \mathrm{per} \mathrm{m}^{2}(7.833 \mathrm{lb}$ per $\left.\mathrm{ft}^{2}\right)$ and would require $151.8 \mathrm{~m}^{2}\left(1634 \mathrm{ft}^{2}\right)$ of content mass. Assuming GWB density of $10 \mathrm{~kg}$ per m $\mathrm{m}^{2}\left(2.08 \mathrm{lb}\right.$ per $\left.\mathrm{ft}^{2}\right)$, a total of $357.3 \mathrm{~m}^{2}\left(3846 \mathrm{ft}^{2}\right)$ of structural mass is required to meet the standard recommendation.

\subsection{Occupancy}

Occupancy is based on the BA Benchmark constant daily occupancy load profile seen in Table 2-8. The profile changes over the hours of the day, but does not vary across days. The house is treated as a single zone with an average internal heat gain of 385.8 $\mathrm{Btu} / \mathrm{person} / \mathrm{hr}$ (113 watts per person). The average number of people varies between all three family members being at home during the night to only 0.73 people present during the middle of the day.

Table 2-8 Occupancy Load Profile as a Proportion of Maximum Occupancy, and Total Occupants, By Hour of the Day

\begin{tabular}{|c|c|c|}
\hline Hour & Load Profile & People \\
\hline $1: 00$ & 1.000 & 3.00 \\
\hline $2: 00$ & 1.000 & 3.00 \\
\hline $3: 00$ & 1.000 & 3.00 \\
\hline $4: 00$ & 1.000 & 3.00 \\
\hline $5: 00$ & 1.000 & 3.00 \\
\hline $6: 00$ & 1.000 & 3.00 \\
\hline $7: 00$ & 1.000 & 3.00 \\
\hline $8: 00$ & 0.883 & 2.65 \\
\hline $9: 00$ & 0.409 & 1.23 \\
\hline $10: 00$ & 0.242 & 0.73 \\
\hline $11: 00$ & 0.242 & 0.73 \\
\hline $12: 00$ & 0.242 & 0.73 \\
\hline
\end{tabular}

\begin{tabular}{|c|c|c|}
\hline Hour & Load Profile & People \\
\hline $13: 00$ & 0.242 & 0.73 \\
\hline $14: 00$ & 0.242 & 0.73 \\
\hline $15: 00$ & 0.242 & 0.73 \\
\hline $16: 00$ & 0.242 & 0.73 \\
\hline $17: 00$ & 0.295 & 0.89 \\
\hline $18: 00$ & 0.553 & 1.66 \\
\hline $19: 00$ & 0.897 & 2.69 \\
\hline $20: 00$ & 0.897 & 2.69 \\
\hline $21: 00$ & 0.897 & 2.69 \\
\hline $22: 00$ & 1.000 & 3.00 \\
\hline $23: 00$ & 1.000 & 3.00 \\
\hline $24: 00$ & 1.000 & 3.00 \\
\hline
\end{tabular}




\subsection{Internal Heat Gains}

Previous sections have addressed specific internal heat gain categories, but it is of interest to summarize these heat gains and determine if they are comparable to the 2009 IECC standard reference design specifications. The total internal heat gains specified by 2009 IECC are based on the following equation. Based on 2009 IECC, total internal heat gains, IGain, should be $20001 \mathrm{kWh} /$ day (68 $292 \mathrm{Btu} /$ day) for the one-story prototype.

$$
\text { IGain }=17,900+23.8 * C F A+4104 * N_{B R}
$$

Internal heat gains originate from domestic hot water use, electrical equipment use, lighting, and human occupancy. Table 2-9 gives internal heat gains resulting from each category based on an EnergyPlus simulation of the prototype. The simulated internal heat gains of $20412 \mathrm{kWh} /$ day (69 $694 \mathrm{Btu} /$ day) are slightly higher than the 2009 IECC standard reference design (2\%).

Table 2-9 Heat Gain Comparison-Reference and Prototype Designs

\begin{tabular}{|l|c|c|c|}
\hline Equipment & $\begin{array}{c}\text { BA Benchmark } \\
\text { kWh (Btu) }\end{array}$ & $\begin{array}{c}\text { 2009 IECC } \\
\text { kWh (Btu) }\end{array}$ & $\begin{array}{c}\text { Prototype Design } \\
\text { kWh (Btu) }\end{array}$ \\
\hline Lighting & NA & NA & $3558(12150)$ \\
\hline Equipment & $9742(33264)$ & NA & $9739(33253)$ \\
\hline Occupancy & $5602(19126)$ & NA & $5602(19128)$ \\
\hline Hot Water & $1512(5161)$ & NA & $1512(5163)$ \\
\hline Total & $N A$ & $20001(68292)$ & $20412(69694)$ \\
\hline
\end{tabular}




\section{Two-Story Building Design Specification}

The second building design represents a typical 2-story, 3-bedroom, slab-on-grade detached house with no garage. This design was chosen because it is the simplest building design and can be used as the framework for more detailed 2-story house designs. In the remainder of this section, each aspect of the building design and operation will be defined.

\subsection{Building Envelope}

There are some building envelope assumptions that are constant regardless of the building location's climate while other assumptions are climate specific. The following two subsections will define each set of assumptions separately.

\subsubsection{General Assumptions}

The prototype is a 2009 IECC compliant 2-story, 3-bedroom, slab-on-grade house. The dimensions are $12.2 \mathrm{~m} \mathrm{x} 7.6 \mathrm{~m}(40 \mathrm{ft} \times 25 \mathrm{ft})$ for a total of $185.8 \mathrm{~m}^{2}\left(2000 \mathrm{ft}^{2}\right)$ of conditioned floor area. The house is oriented $12.2 \mathrm{~m}(40 \mathrm{ft})$ east to west and $7.6 \mathrm{~m}(25 \mathrm{ft})$ north to south. The first and second floors have $2.4 \mathrm{~m}(8 \mathrm{ft})$ high ceilings. The roof slope is assumed to be $4: 12$ with $0.3 \mathrm{~m}$ (1 ft) overhangs on the north and south sides of the building. There is assumed to be no garage in the prototype.

The house is built to meet 2009 IECC for low-rise residential buildings. The EnergyPlus parameters for the materials used in the exterior envelope (excluding the roof) are estimated using an average transmittance with the surface-weighted path fractions. In other words, using a simple weighted average of parameter values based on the percentage of framing in the surface. This approach is reasonable for materials with similar R-values and thickness. The roof and interior floor control for varying materials by splitting the surface into two separate surfaces. The framing percentage for each surface type is shown in Table 3-1.

Table 3-1 Material Parameter Calculation Approach

\begin{tabular}{|l|c|c|}
\hline \multicolumn{1}{|c|}{ Construction } & Pct. Frame & Approach \\
\hline Exterior Wall & $23 \%$ & surface-weighted path fractions \\
\hline Top Floor Ceiling & $11 \%$ & surface-weighted path fractions \\
\hline Roof & $11 \%$ & split into separate surfaces \\
\hline Interior Floor & $13 \%$ & split into separate surfaces \\
\hline
\end{tabular}


The exterior wall is assumed to be $3.8 \mathrm{~cm} \times 8.9 \mathrm{~cm}(1.5 \mathrm{in} \times 3.5$ in) wood-framed $41 \mathrm{~cm}$ (16 in) on center (OC) with cavity insulation ( $9 \mathrm{~cm}$ (3.42 in) fiberglass batts at R-3.8 per $2.5 \mathrm{~cm}(1 \mathrm{in}))$. The material layers for the exterior wall are defined in Figure 3-1. The construction is made of 5 or 6 layers depending on IECC requirements: wood siding, a felt vapor barrier, rigid insulation (if required), plywood sheathing, $3.8 \mathrm{~cm} \times 8.9 \mathrm{~cm}$ (1.5 in x 3.5 in) framing with batt insulation in wall cavity, and gypsum wall board (GWB).

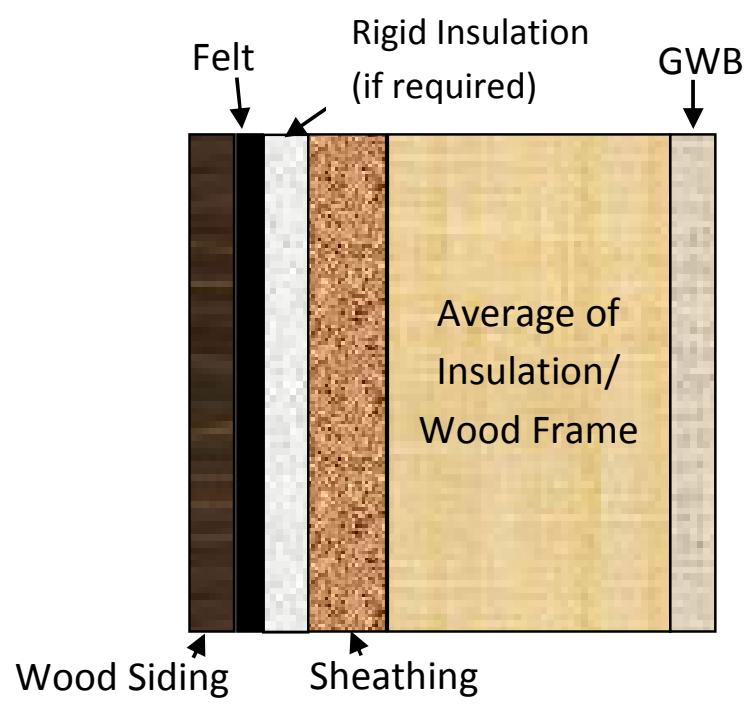

\section{Figure 3-1 Building material layers for exterior wall}

The average conductance (U-factor) of the framing/insulation combination material is calculated by the following equation from ASHRAE Fundamentals Handbook (2009):

$$
U_{A V G}=23 \% * U_{\text {FRAME }}+77 \% * U_{\text {INSULATION }}
$$

For this material, $23 \%$ of the wall area is framing with the remaining $77 \%$ being the wall cavity that is filled with cavity insulation.

The second floor ceiling is assumed to be $1.3 \mathrm{~cm}(0.5 \mathrm{in}) \mathrm{GWB}$ with $3.8 \mathrm{~cm} \times 14.0 \mathrm{~cm}$ ( 1.5 in $x 5.5$ in) ceiling joists. There is blown-in cellulose insulation in the open cavity plus any additional inches of blown-in insulation as required by 2009 IECC. The amount of blown-in insulation varies by climate zone, and will be described in Section 3.1.2. The average material $\mathrm{U}$-factor is calculated in the same manner as the exterior wall. Framing accounts for $11 \%$ of the ceiling surface. The material layers for the ceiling are defined in Figure 3-2. 


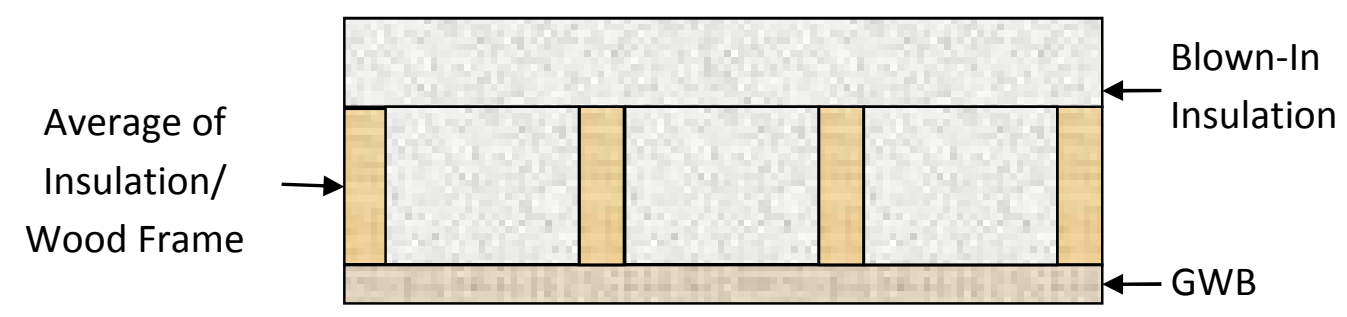

Figure 3-2 Building material layers for ceiling

The roof construction is assumed to be $3.8 \mathrm{~cm} \times 14.0 \mathrm{~cm}$ ( $1.5 \mathrm{in} \mathrm{x} 5.5$ in) rafters with $1.3 \mathrm{~cm}(0.5 \mathrm{in})$ plywood sheathing, felt paper, and asphalt shingles. There is no insulation in the rafters, which makes it unrealistic to calculate an average U-factor. Instead the roof is split into two surfaces for energy simulation, one with framing (23\% of roof area) and one without framing ( $77 \%$ of roof area). The material layers for the roof with framing are defined in Figure 3-3.

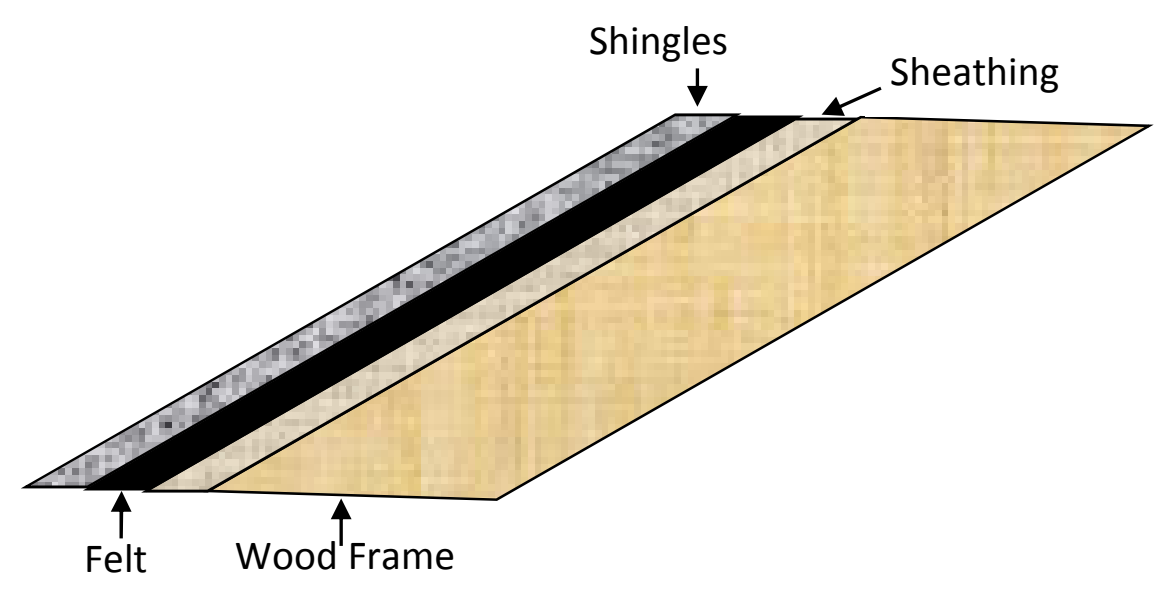

Figure 3-3 Building material layers for roof

The interior floor/ceiling (first floor ceiling/second floor ceiling) construction is assumed to be $3.8 \mathrm{~cm} \times 19.1 \mathrm{~cm}$ (1.5 in x 7.5 in) floor joists with $1.6 \mathrm{~cm}(5 / 8 \mathrm{in})$ plywood subflooring and $100 \%$ carpet finish. The framing accounts for $13 \%$ of the floor. No insulation is required for interior surfaces because there is no thermal benefit from restricting thermal transfer within the same zone.

The foundation is a $10 \mathrm{~cm}$ ( $4 \mathrm{in}$ ) concrete slab. The floor finish is assumed to be $40 \%$ carpet, $40 \%$ hardwood, $15 \%$ vinyl tile, and $5 \%$ ceramic tile (based on RSMeans Square Foot Costs). Some climate zones require rigid insulation to be placed on the slab edge, which will be described in Section 3.1.2. The material layers for the slab are defined in Figure 2-4. The EnergyPlus Slab preprocessor is used to simulate the heat transfer between the ground and the slab, which recommends simulating horizontal insulation 
under the slab instead of vertical insulation on the edge of the slab for "slab-on-grade" foundations because the energy transfer that occurs on the vertical edges of the slab are significantly smaller than the energy transfer from the surface area contacting the ground. The Slab preprocessor assumes that the bottom of the slab is flush with the grade.

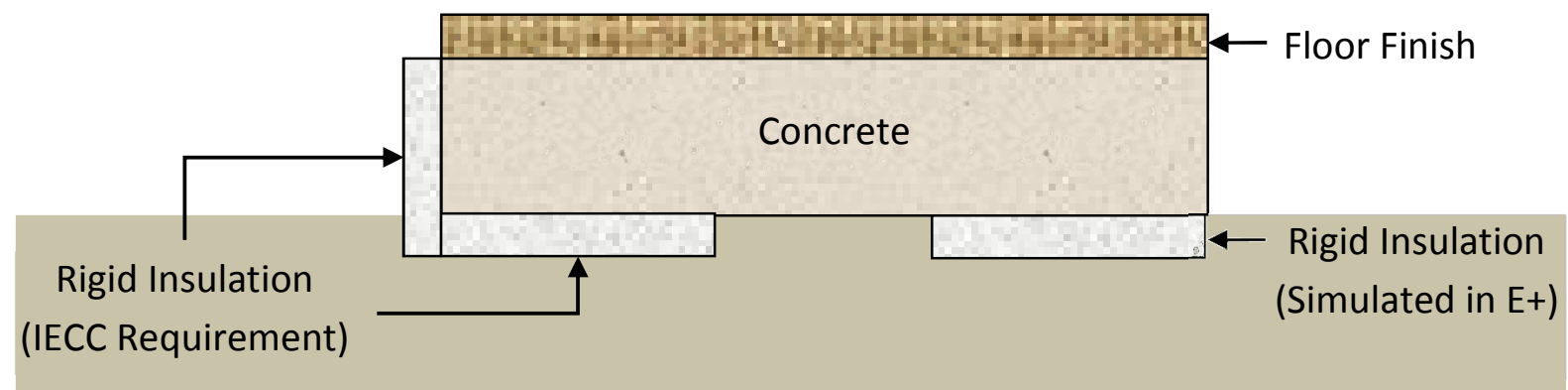

Figure 3-4 Building material layers for slab-on-grade

Window glazing area is assumed to be $15 \%$ of conditioned floor area and is split between the four exterior walls based on wall area. Two $1.2 \mathrm{~m}(4 \mathrm{ft})$ high windows on each side of the house for each floor (16 in total) are assumed to be located at an equal distance from the wall edge. The width of the windows is based on the fraction of total wall area represented by each side. There are assumed to be two $0.9 \mathrm{~m} \times 2.0 \mathrm{~m} \mathrm{(3 \textrm {ft } x 6 \mathrm { ft }}$ 8 in) $-4.4 \mathrm{~cm}$ (1.75 in) solid pine wood doors, located in the center of the wall on the north and south walls. Windows are defined in EnergyPlus using the "Simple Glazing System," which requires only 3 parameters: U-factor $\left(\mathrm{W} / \mathrm{m}^{2} \cdot \mathrm{K}\right)$, solar heat gain coefficient (SHGC), and visible transmittance (VT). These parameters vary by climate zone, and will be described in Section 3.1.2.

\subsubsection{Climate Zone-Specific Assumptions}

The exterior envelope performance requirements of 2009 IECC vary depending on the climate zone. Table 3-2 is an abridged version of Table 402.1.1 found in Chapter 4: Residential Energy Efficiency of the 2009 IECC. A map of the climate zones by county is found in the appendix. 
Table 3-2 2009 IECC energy code requirements for exterior envelope

\begin{tabular}{|c|c|c|c|c|c|c|}
\hline Climate Zone & $\begin{array}{c}\text { Fenestration } \\
\text { U-Factor } \\
\left(\mathrm{W} / \mathrm{m}^{2} \cdot \mathrm{K}\right)\end{array}$ & $\begin{array}{c}\text { Glazed } \\
\text { Fenestration } \\
\text { SHGC }\end{array}$ & $\begin{array}{l}\text { Ceiling } \\
\text { R-Value }\end{array}$ & Wood Frame Wall R-Value & $\begin{array}{l}\text { Slab Edge } \\
\text { R-Value }\end{array}$ & Slab Depth \\
\hline 1 & 1.2 & 0.30 & $5.3(30)$ & $2.3(13)$ & $0(0)$ & $0(0)$ \\
\hline 2 & 0.65 & 0.30 & $5.3(30)$ & $2.3(13)$ & $0(0)$ & $0(0)$ \\
\hline 3 & 0.50 & 0.30 & $5.3(30)$ & $2.3(13)$ & $0(0)$ & $0(0)$ \\
\hline 4 except Marine & 0.35 & NR* & $6.7(38)$ & $2.3(13)$ & $1.8(10)$ & $0.61 \mathrm{~m}(2 \mathrm{ft})$ \\
\hline 5 and 4 Marine & 0.35 & $\mathrm{NR}^{*}$ & $6.7(38)$ & $3.5(20)$ or $2.3+0.88(13+5)^{* *}$ & $1.8(10)$ & $0.61 \mathrm{~m}(2 \mathrm{ft})$ \\
\hline 6 & 0.35 & NR* & $8.6(49)$ & $3.5(20)$ or $2.3+0.88(13+5)^{* *}$ & $1.8(10)$ & $1.21 \mathrm{~m} \mathrm{(4 \textrm {ft } )}$ \\
\hline 7 and 8 & 0.35 & $\mathrm{NR}^{*}$ & $8.6(49)$ & $3.7(21)$ & $1.8(10)$ & $1.21 \mathrm{~m}(4 \mathrm{ft})$ \\
\hline
\end{tabular}

Although EnergyPlus requires three parameters to define windows, 2009 IECC only specifies two: U-factor and SHGC. The U-factor is allowed to be as high as 1.2 in Zone 1 to as low as 0.35 in Zones 7 and 8. The SHGC must be less than 0.30 for Zones 1 through 3 , but has no requirement for Zones 4 through 8 . The SHGC for the standard reference design specified in 2009 IECC is 0.40 for Zones 4 through 8 . The visible transmittance is not restricted in 2009 IECC for any climate zones, and is assumed to be 0.16 for Zone 1 , 0.22 for Zone 2, 0.46 for Zone 3, and 0.40 for Zones 4 through $8 .^{13}$

The insulation R-values for the exterior walls, ceiling, and foundation increase as the climate zone gets colder. The exterior wall R-value ranges from R-13 in Zones 1 through 4 to R-21 in Zones 7 and 8. The first R-13 is met with high density cavity insulation in the wall cavity. Additional R-value is met by adding rigid insulation to the exterior of the wall. The ceiling R-value ranges from R-30 in Zones 1 through 3 to R-49 in Zones 6 through 8. Additional cellulose blown-in insulation used to reach the required R-value. $\mathrm{R}-10$ insulation under the foundation is required in Zones 4 through 8 only, which is met by adding $10 \mathrm{~cm}$ ( 2 in) of extruded polystyrene (XPS) below the slab.

\footnotetext{
${ }^{13}$ Visible transmittance values are based on window characteristics defined in the ASHRAE Fundamentals Handbook (2009).
} 


\subsection{Heating, Ventilating, and Air Conditioning Equipment}

The HVAC system in the prototype building design is a single-speed unitary system with an air conditioner with a Seasonal Energy Efficiency Ratio (SEER) rating of $13,{ }^{14}$ and a gas furnace with annual fuel utilization efficiency (AFUE) of $78 \%$ (both current minimum federal energy efficiency requirements). No dehumidification option or economizer is included in the system. The supply fan is assumed to cycle, and has a total efficiency of $70 \%$. The supply fan motor efficiency is $90 \%$. The first and second floors are assumed to be a single zone, with the HVAC equipment located on the first floor. The ductwork is assumed to be within the conditioned space, which leads to zero energy loss from the ductwork. These two assumptions assist in simplifying the model, and will be relaxed in future research to account for split systems and the resulting duct leakage. ${ }^{15}$

\subsection{Operating Conditions}

The thermostat setpoints are based on the standard reference designs defined in 2009 IECC, which are $23.9^{\circ} \mathrm{C}\left(75^{\circ} \mathrm{F}\right)$ cooling and $22.2^{\circ} \mathrm{C}\left(72^{\circ} \mathrm{F}\right)$ heating.

\subsection{Air Infiltration and Mechanical Ventilation}

The mechanical ventilation rate is based on ASHRAE Standard 62.2-2010. The Minimum Outdoor Air Flow Rate (liters per second) is based on ASHRAE 62.2-2010 equation 4.1b:

$$
0.05 * m^{2}+3.5 *\left(N_{B R}+1\right)
$$

For the prototype design's $185.6 \mathrm{~m}^{2}\left(2000 \mathrm{ft}^{2}\right)$ and 3 bedrooms, the total house ventilation rate is $0.0236 \mathrm{~m}^{3}$ per second ( $50 \mathrm{ft}^{3}$ per minute). The ASHRAE 62.2-2010 requirements have a built-in $0.15 \mathrm{ACH}$ of air leakage. Door infiltration is assumed to be included in the $\mathrm{ACH}^{16}$

The prescriptive maximum air leakage of 7 air changes per hour (ACH) at 50 pascals specified in Section 402.4.2.1 of the 2009 IECC is not defined under realistic conditions. For this reason, leakage is based on ASHRAE 62.2-2010.

Table 405.5.2(1) of the 2009 IECC specifies that "residences with mechanical ventilation that are test in accordance with ASHRAE 119, Section 5.1, the measured air exchange rate combined with the mechanical ventilation rate...shall not be less than" the ASHRAE

\footnotetext{
${ }^{14}$ The 13 SEER rating converts to a Coefficient of Performance (COP) of 3.28 for the EnergyPlus simulation based on the following equation: $C O P=\left(-0.02 * S E E R^{2}+1.12 * S E E R\right) / 3.412$.

${ }^{15} 2009$ IECC prescriptive requirements include a duct tightness post-construction test showing duct leakage less than or equal to $226.5 \mathrm{~L} / \mathrm{min}(8 \mathrm{CFM})$ per $9.29 \mathrm{~m}^{2}\left(100 \mathrm{ft}^{2}\right)$ at $25 \mathrm{Pascal}(\mathrm{Pa})$.

${ }^{16}$ According to the ASHRAE Fundamentals Handbook, "In residences...air exchange associated with a door can be estimated based on air leakage through cracks between door and frame.
} 
62.2-2010 minimum outdoor air flow rate. As assumed in ASHRAE 62.2-2010, the air infiltration rate is assumed to be $0.15 \mathrm{ACH}$.

The standard reference design in 2009 IECC assumes the attic is vented with venting equivalent to 1 unit per 300 units of the ceiling area, which converts to an effective leakage area (ELA) of $3096.8 \mathrm{~cm}^{2}\left(3.33 \mathrm{ft}^{2}\right)$.

\subsection{Domestic Hot Water}

The BA Benchmark functions defined in Table 3-3 are used instead of 2009 IECC to estimate the hot water consumption of each piece of equipment and activities. Total hot water consumption based on the BA Benchmark is 303 liters ( 80 gallons) which are the same as in the 1-story prototype because the number of bedrooms is equal. These estimates are used for the analysis because they break down consumption by end use; the 2009 IECC estimate is for total hot water consumption only. The clothes washer and dishwasher use only hot water $48.9^{\circ} \mathrm{C}\left(120^{\circ} \mathrm{F}\right)$ while the showers, baths, and sinks use hot water that is tempered to $40.6^{\circ} \mathrm{C}\left(105^{\circ} \mathrm{F}\right)$, as shown in Table 3-3. Since some of the water consumed is tempered with cold water, the total hot water drawn from the hot water tank is 273 liters ( 72.5 gallons) per day.

\section{Table 3-3 Hot Water Consumption}

\begin{tabular}{|c|c|c|c|}
\hline Equipment & Water Temp. & $\begin{array}{c}\text { Function } \\
\text { Liters (Gallons) }\end{array}$ & $\begin{array}{c}\text { Liters (Gallons) } \\
\text { Per Day }\end{array}$ \\
\hline Clothes Washer & $48.9^{\circ} \mathrm{C}\left(120^{\circ} \mathrm{F}\right)$ & $28+10 * \mathrm{~N}_{\mathrm{BR}}\left(7.5+2.5 * \mathrm{~N}_{\mathrm{BR}}\right)$ & $56.8(15)$ \\
\hline Dishwasher & $48.9^{\circ} \mathrm{C}\left(120^{\circ} \mathrm{F}\right)$ & $10+3 * \mathrm{~N}_{\mathrm{BR}}\left(2.5+0.833^{*} \mathrm{~N}_{\mathrm{BR}}\right)$ & $18.9(5)$ \\
\hline Showers & $40.6^{\circ} \mathrm{C}\left(105^{\circ} \mathrm{F}\right)$ & $53+18 * \mathrm{~N}_{\mathrm{BR}}\left(14.0+4.67 * \mathrm{~N}_{\mathrm{BR}}\right)$ & $106.0(28)$ \\
\hline Baths & $40.6^{\circ} \mathrm{C}\left(105^{\circ} \mathrm{F}\right)$ & $13+4 * \mathrm{~N}_{\mathrm{BR}}\left(3.5+1.17 * \mathrm{~N}_{\mathrm{BR}}\right)$ & $26.5(7)$ \\
\hline \multirow[t]{2}{*}{ Sinks } & $40.6^{\circ} \mathrm{C}\left(105^{\circ} \mathrm{F}\right)$ & $47+16 * \mathrm{~N}_{\mathrm{BR}}\left(12.5+4.16 * \mathrm{~N}_{\mathrm{BR}}\right)$ & $94.6(25)$ \\
\hline & & Total: & $303(80)$ \\
\hline
\end{tabular}

The BA Benchmark total water use, daily water use load profiles, and sensible (temperature-based) and latent (humidity-based) loads for hot water use are used to estimate the real-time hot water use and the resulting internal heat gains. The daily load profiles, or proportion of peak flow rate by hour of the day, for each hot water use category can be seen in Figure 3-5. 

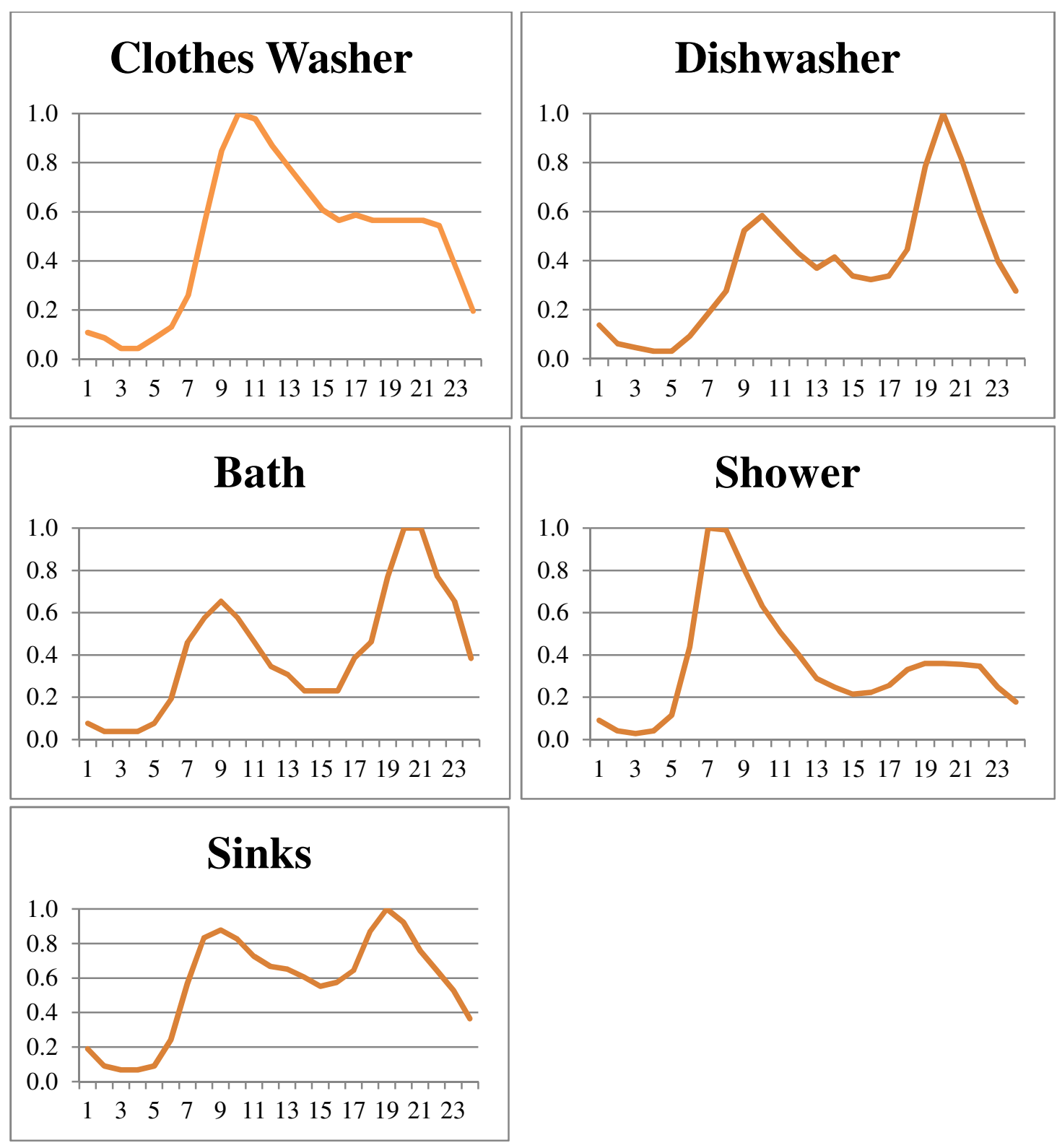

Figure 3-5 Domestic Hot Water Load Profiles as a Proportion of Peak Flow Rate, By Hour of the Day

Internal heat gains from hot water for the clothes washer and dishwasher are assumed to be zero for both sensible and latent loads. Any heat gains for this equipment are included in the equipment electricity use heat gains. The sensible and latent load fractions for shower, bath, and sinks are reverse engineered from internal heat gains estimated using the BA Benchmark functions in Table 3-4. 
Table 3-4 Domestic Hot Water Internal Heat Gains

\begin{tabular}{|l|c|c|c|c|c|c|}
\hline \multirow{2}{*}{$\begin{array}{c}\text { Equipment } \\
\text { End Use }\end{array}$} & \multicolumn{3}{|c|}{ Sensible Load } & \multicolumn{3}{c|}{ Latent } \\
\cline { 2 - 7 } & $\begin{array}{c}\text { Function } \\
\text { kWh (Btu) }\end{array}$ & $\begin{array}{c}\text { Heat Gain } \\
\text { kWh (Btu) }\end{array}$ & $\begin{array}{c}\text { Load } \\
\text { Fraction }\end{array}$ & $\begin{array}{c}\text { Function } \\
\text { kWh (Btu) }\end{array}$ & $\begin{array}{c}\text { Heat Gain } \\
\text { kWh (Btu) }\end{array}$ & $\begin{array}{c}\text { Load } \\
\text { Fraction }\end{array}$ \\
\hline Showers & $\begin{array}{c}0.22+0.07 * \mathrm{~N}_{\mathrm{BR}} \\
\left(741+247 * \mathrm{~N}_{\mathrm{BR}}\right)\end{array}$ & $0.4(1482)$ & 0.1947 & $\begin{array}{c}0.21+0.07 * \mathrm{~N}_{\mathrm{BR}} \\
\left(703+235 * \mathrm{~N}_{\mathrm{BR}}\right)\end{array}$ & $0.4(1408)$ & 0.0055 \\
\hline Baths & $0.05+0.02 * \mathrm{~N}_{\mathrm{BR}}$ & $0.4(1371)$ & 0.7262 & $0(0)$ & $0(0)$ & 0.0000 \\
\hline Sinks & $\left(185+62 * \mathrm{~N}_{\mathrm{BR}}\right)$ & & & & & 0.0012 \\
& $0.09+0.03 * \mathrm{~N}_{\mathrm{BR}}$ & $0.2(619)$ & 0.0917 & $\begin{array}{c}0.04+0.01 * \mathrm{~N}_{\mathrm{BR}} \\
\left(140+47 * \mathrm{~N}_{\mathrm{BR}}\right)\end{array}$ & $0.1(281)$ & \\
\hline
\end{tabular}

Based on 2009 IECC, the water heater must meet federal energy efficiency requirements. The water heater is assumed to be a gas water heater with a perfectly mixed storage tank with an efficiency of $76 \%,{ }^{17}$ a firing rate of $10551 \mathrm{~W},{ }^{18}$ and a setpoint temperature of $48.9^{\circ} \mathrm{C}\left(120^{\circ} \mathrm{F}\right)$. The heat loss coefficient from the water heater to the ambient temperature in the internal space is assumed to be $2.1 \mathrm{~W} / \mathrm{K} .{ }^{19}$

\subsection{Lighting}

The lighting load profiles and electricity consumption are based on the profile in the BA Benchmark that separates the house into living and sleeping zones. ${ }^{20}$ Total electricity use is estimated based on the same two-stage process defined in the BA Benchmark except the loads are split equally between the two floors, which can be seen in Table 3-5. The baseline lighting estimate is based on $86 \%$ incandescent and $14 \%$ fluorescent use. The lighting requirements in 2009 IECC require $50 \%$ high efficacy lighting, which is met by using $50 \%$ CFL lighting. The BA Benchmark adjustment functions shown in the right in Table 3-5 are used to adjust the total electricity consumption estimation to represent the greater efficiency required by 2009 IECC. The baseline annual total lighting electricity consumption is estimated at $2281 \mathrm{kWh}$. The 2009 IECC compliant lighting decreases lighting electricity consumption by $36 \%$ to $1411 \mathrm{kWh}$.

\footnotetext{
${ }^{17}$ Minimum federal efficiency requirement for gas water heaters

${ }^{18}$ Based on the BA Benchmark for a 3 bedroom/2 bathroom house with a gas unit

${ }^{19}$ Based on NIST expert recommendation

${ }^{20}$ Splitting the lighting loads profiles will allow an easier transition if multiple zoning options are introduced into the prototypes in the future.
} 
Table 3-5 Annual Lighting Electricity Consumption

\begin{tabular}{|l|c|r|c|r|r|}
\hline \multirow{2}{*}{$\begin{array}{l}\text { Lighting Use } \\
\text { Category }\end{array}$} & \multicolumn{2}{|c|}{ Baseline } & \multicolumn{2}{c|}{ 2009 IECC } \\
\cline { 2 - 6 } & Function & $\begin{array}{l}\text { Total } \\
\text { kWh }\end{array}$ & $\begin{array}{c}\text { Total } \\
\text { kWh }\end{array}$ & $\begin{array}{c}\text { kWh/ } \\
\text { Floor }\end{array}$ \\
\hline Hard-wired & $0.8 *(\mathrm{CFA} * 0.737+467)$ & 1553 & $1553 *\left[\left(\mathrm{~F}_{\mathrm{INC}}+0.14\right)+\left(\mathrm{F}_{\mathrm{CFL}}-0.14\right) * 0.27\right]$ & 1145 & 573 \\
\hline Plug-In & $0.2 *(\mathrm{CFA} * 0.737+467)$ & 388 & $388^{*}\left[\left(\mathrm{~F}_{\mathrm{INC}}+0.14\right)+\left(\mathrm{F}_{\mathrm{CFL}}-0.14\right) * 0.27\right]$ & 286 & 143 \\
\hline Exterior & $\mathrm{CFA} 0.17$ & 340 & $340 *\left[\left(\mathrm{~F}_{\mathrm{INC}}+0.14\right)+\left(\mathrm{F}_{\mathrm{CFL}}-0.14\right) * 0.27\right]$ & 251 & $\mathrm{NA}$ \\
\hline Total & $\mathrm{CFA} 0.907+467$ & 2281 & $2281 *\left[\left(F_{I N C}+0.14\right)+\left(F_{C F L}-0.14\right) * 0.27\right]$ & 1682 & $N A$ \\
\hline
\end{tabular}

The load profiles (proportion of peak wattage in use) for interior lighting can be seen in Table 3-6. The total wattage parameter for lighting in EnergyPlus is reverse engineered from the peak consumption load profiles and the total electricity consumption estimates. The load profile for exterior lighting assumes the lights are on sunset to sunrise.

Table 3-6 Lighting Load Profiles as a Proportion of Peak Wattage in Use, By Hour of the Day

\begin{tabular}{|c|c|c|}
\hline Hour & Living & Sleeping \\
\hline $1: 00$ & 0.06 & 0.6700 \\
\hline $2: 00$ & 0.06 & 0.6700 \\
\hline $3: 00$ & 0.06 & 0.6700 \\
\hline $4: 00$ & 0.06 & 0.6700 \\
\hline $5: 00$ & 0.1201 & 0.2667 \\
\hline $6: 00$ & 0.2402 & 0.5837 \\
\hline $7: 00$ & 0.2792 & 0.6336 \\
\hline $8: 00$ & 0.2691 & 0.5333 \\
\hline $9: 00$ & 0.1387 & 0.2000 \\
\hline $10: 00$ & 0.1387 & 0.0667 \\
\hline $11: 00$ & 0.1387 & 0.0667 \\
\hline $12: 00$ & 0.1387 & 0.0667 \\
\hline
\end{tabular}

\begin{tabular}{|c|c|c|}
\hline Hour & Living & Sleeping \\
\hline $13: 00$ & 0.1387 & 0.0667 \\
\hline $14: 00$ & 0.1387 & 0.0667 \\
\hline $15: 00$ & 0.1387 & 0.0667 \\
\hline $16: 00$ & 0.2591 & 0.0835 \\
\hline $17: 00$ & 0.5486 & 0.1832 \\
\hline $18: 00$ & 0.7659 & 0.2661 \\
\hline $19: 00$ & 0.9451 & 0.4992 \\
\hline $20: 00$ & 1.000 & 0.7995 \\
\hline $21: 00$ & 0.9006 & 1.0000 \\
\hline $22: 00$ & 0.5178 & 0.8667 \\
\hline $23: 00$ & 0.2777 & 0.4963 \\
\hline $24: 00$ & 0.1201 & 0.2000 \\
\hline
\end{tabular}




\subsection{Appliances and Miscellaneous Electrical Loads}

The electrical equipment in the house includes a refrigerator, clothes washer, clothes dryer, dishwasher, electric range, and a combination of variable miscellaneous electrical loads (MELs). MELs encompass electronics such as computers, televisions, stereos, and other plug loads. The electricity consumption for each category is based on the BA Benchmark functions seen in Table 3-7. Electricity consumption is usually a function of the number of bedrooms in the home $\left(\mathrm{N}_{\mathrm{BR}}\right)$. The only category that will see an increase in electrical consumption is MELs because one variable in its function is square foot of conditioned floor area.

Table 3-7 Appliance and MEL Electricity Consumption

\begin{tabular}{|l|c|r|}
\hline \multicolumn{1}{|c|}{ Equipment } & Function & kWh \\
\hline Refrigerator & Constant & 669 \\
\hline Clothes Washer & $52.5+17.5 * \mathrm{~N}_{\mathrm{BR}}$ & 105 \\
\hline Clothes Dryer & $418+139^{*} \mathrm{~N}_{\mathrm{BR}}$ & 835 \\
\hline Dishwasher & $103+34.3 * \mathrm{~N}_{\mathrm{BR}}$ & 206 \\
\hline Electric Range & $302+101^{*} \mathrm{~N}_{\mathrm{BR}}$ & 605 \\
\hline Variable MELs & $1281+\left(196^{*} \mathrm{~N}_{\mathrm{BR}}\right)+\left(0.345^{*} \mathrm{CFA}\right)$ & 2559 \\
\hline & & Total: \\
\hline
\end{tabular}

The BA Benchmark load profiles in Figure 3-6 create a real-time variation in electricity consumption for each category. Appliances such as the electric range and dishwasher have a significant variation in time-of-day use while refrigerator use only varies slightly over a day. 


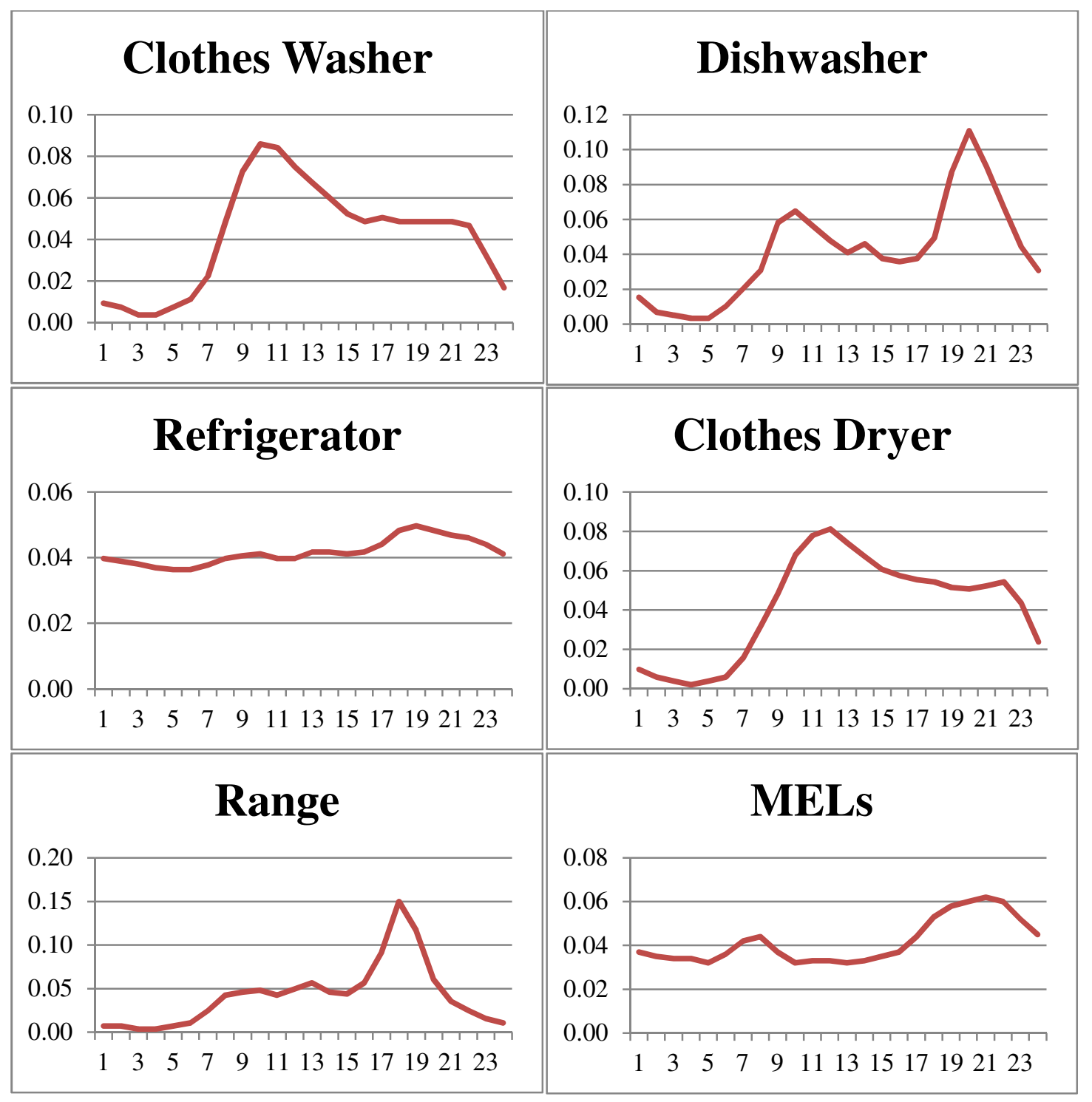

Figure 3-6 Domestic Hot Water Load Profiles as a Proportion of Peak Use, By Hour of the Day

\subsection{Internal Mass}

Instead of defining individual interior surfaces and furniture, internal mass is estimated based on ASHRAE 90.2-2007 recommendations. There is assumed to be $3.6 \mathrm{~kg}(8 \mathrm{lb})$ of $5 \mathrm{~cm}$ ( $2 \mathrm{in}$ ) thick wood per square foot of conditioned space for contents for a total of $7257 \mathrm{~kg}(16000 \mathrm{lb})$. There is assumed to be $2.3 \mathrm{~kg}(5 \mathrm{lb})$ of $1.3 \mathrm{~cm}(0.5 \mathrm{in})$ gypsum wall board (GWB) per square foot of conditioned space for the internal structure for a total of $4536 \mathrm{~kg}(10000 \mathrm{lb})$.

EnergyPlus estimates internal mass in terms of square meters of material open to the zone air. Based on the total weight of the two materials (wood and GWB) and their weight per 
inch, it is possible to determine the comparable surface area needed to match the amount of internal mass required. Assuming the wood density is equivalent to that of white oak, $753 \mathrm{~kg} \mathrm{per} \mathrm{m}^{3}\left(47 \mathrm{lb}\right.$ per $\left.\mathrm{ft}^{3}\right)$, the $5 \mathrm{~cm}\left(2\right.$ in) thick wood weighs $38 \mathrm{~kg} \mathrm{per} \mathrm{m}^{2}(7.833 \mathrm{lb}$ per $\left.\mathrm{ft}^{2}\right)$ and would require $189.8 \mathrm{~m}^{2}\left(2043 \mathrm{ft}^{2}\right)$ of content mass. Assuming GWB density of $10 \mathrm{~kg}$ per m $\mathrm{m}^{2}\left(2.08 \mathrm{lb}\right.$ per $\left.\mathrm{ft}^{2}\right)$, a total of $446.6 \mathrm{~m}^{2}\left(4808 \mathrm{ft}^{2}\right)$ of structural mass to meet the standard recommendations.

\subsection{Occupancy}

Occupancy is based on the BA Benchmark constant daily occupancy load profiles split into living and sleeping zones as seen in Table 3-8. The profiles change over the hours of the day, but do not vary across days. Separate internal heat gain values are used for each type of occupancy. Occupancy in the living and sleeping areas are assumed to emit $420 \mathrm{Btu} /$ person/hour (123 watts per person) and $350 \mathrm{Btu} /$ person/hour (103 watts per person), respectively.

Table 3-8 Occupancy Load Profile as a Proportion of Maximum Occupancy, By Hour of the Day

\begin{tabular}{|c|c|c|}
\hline Hour & Living & Sleeping \\
\hline $1: 00$ & 0.000 & 1.000 \\
\hline $2: 00$ & 0.000 & 1.000 \\
\hline $3: 00$ & 0.000 & 1.000 \\
\hline $4: 00$ & 0.000 & 1.000 \\
\hline $5: 00$ & 0.000 & 1.000 \\
\hline $6: 00$ & 0.000 & 1.000 \\
\hline $7: 00$ & 0.344 & 0.656 \\
\hline $8: 00$ & 0.500 & 0.383 \\
\hline $9: 00$ & 0.409 & 0.000 \\
\hline $10: 00$ & 0.242 & 0.000 \\
\hline $11: 00$ & 0.242 & 0.000 \\
\hline $12: 00$ & 0.242 & 0.000 \\
\hline
\end{tabular}

\begin{tabular}{|c|c|c|}
\hline Hour & Living & Sleeping \\
\hline $13: 00$ & 0.242 & 0.000 \\
\hline $14: 00$ & 0.242 & 0.000 \\
\hline $15: 00$ & 0.242 & 0.000 \\
\hline $16: 00$ & 0.242 & 0.000 \\
\hline $17: 00$ & 0.295 & 0.000 \\
\hline $18: 00$ & 0.553 & 0.000 \\
\hline $19: 00$ & 0.897 & 0.000 \\
\hline $20: 00$ & 0.897 & 0.000 \\
\hline $21: 00$ & 0.897 & 0.000 \\
\hline $22: 00$ & 1.000 & 0.000 \\
\hline $23: 00$ & 0.500 & 0.500 \\
\hline $24: 00$ & 0.000 & 1.000 \\
\hline
\end{tabular}




\subsection{Internal Heat Gains}

Previous sections have addressed specific internal heat gain categories, but it is of interest to summarize these heat gains and determine if they are comparable to the 2009 IECC standard reference design specifications. The total internal heat gains specified by 2009 IECC are based on the following equation. Based on 2009 IECC, total internal heat gains, IGain, should be $22.8 \mathrm{kWh} /$ day (77 $812 \mathrm{Btu} /$ day) for the two-story prototype.

$$
\text { IGain }=17900+23.8 * C F A+4104 * N_{B R}
$$

Internal heat gains originate from domestic hot water use, electrical equipment use, lighting, and human occupancy. Table 3-9 gives internal heat gains resulting from each category based on an EnergyPlus simulation of the prototype. The simulated internal heat gains of 21.1 (71 972 Btu/day) are lower than the 2009 IECC standard reference design ( $7 \%)$. The variation is likely a result of the number of bedrooms assumed in the prototype. $^{21}$

Table 3-9 Heat Gain Comparison-Reference and Prototype Designs

\begin{tabular}{|l|c|c|c|}
\hline Equipment & $\begin{array}{c}\text { BA Benchmark } \\
\text { kWh (Btu) }\end{array}$ & $\begin{array}{c}\text { 2009 IECC } \\
\text { kWh (Btu) }\end{array}$ & $\begin{array}{c}\text { Prototype Design } \\
\text { kWh (Btu) }\end{array}$ \\
\hline Lighting & NA & NA & $3.9(13374)$ \\
\hline Equipment & $9.9(33716)$ & NA & $10.1(34366)$ \\
\hline Occupancy & $5.6(19028)$ & NA & $5.6(19071)$ \\
\hline Hot Water & $1.5(5161)$ & NA & $1.5(5183)$ \\
\hline Total & $N A$ & $22.8(77812)$ & $21.1(71972)$ \\
\hline
\end{tabular}

\footnotetext{
${ }^{21}$ Increasing the number of bedrooms from 3 to 4 would likely result in total internal heat gains above the 2009 IECC estimate because much of the heat gains are based on the number of bedrooms in the house.
} 


\section{Recommendations for Future Research}

\subsection{Expansion of Current Prototypes}

These two prototype designs are non-location specific and serve as a basis from which additional prototypes can be designed. Alterations to these two prototype designs should include selecting the location of the building, changing the square footage, changing the foundation type, adding a garage, changing orientation, changing the heating fuel type, and designing to meet different editions of the IECC.

\subsection{Location-Specific Factors}

The prototype design is location neutral. For energy simulation, each location requires its own weather file as well as specification of the following local parameters: location, ground temperature, water mains temperature, and design days. ${ }^{22}$

\subsection{Additional Building Sizes}

Leaving the house dimension ratios the same at approximately 2.56:1 and 1.60:1 for the 1-story and 2-story prototypes, respectively, the prototypes can be expanded or contracted to meet the building sizes described in Table 4-1.

Table 4-1 Additional Prototype Sizes

\begin{tabular}{|c|c|c|}
\hline \multicolumn{3}{|c|}{ 1-Story Prototypes } \\
\hline $\mathbf{m}^{\mathbf{2}}\left(\mathbf{f t}^{2}\right)$ & Dimensions m $(\mathbf{f t})$ & BR \\
\hline $111.6(1201)$ & $6.6 \times 16.9(21.67 \times 55.42)$ & 3 \\
\hline $148.6(1600)$ & $7.6 \times 19.5(25.0 \times 64.0)$ & 3 \\
\hline $176.6(1901)$ & $8.3 \times 21.3(27.25 \times 69.75)$ & 3 \\
\hline $214.0(2303)$ & $9.1 \times 23.4(30.0 \times 76.75)$ & 4 \\
\hline $287.3(3093)$ & $10.6 \times 27.1(34.75 \times 89.0)$ & 5 \\
\hline
\end{tabular}

\begin{tabular}{|c|c|c|}
\hline \multicolumn{3}{|c|}{ 2-Story Prototypes } \\
\hline $\mathbf{m}^{\mathbf{2}}\left(\mathbf{f t}^{\mathbf{2}}\right)$ & Dimension m (ft) & BR \\
\hline $148.8(1602)$ & $6.8 \times 10.9(22.37 \times 35.8)$ & 3 \\
\hline $202.9(2184)$ & $7.9 \times 12.8(26.0 \times 42.0)$ & 4 \\
\hline $241.0(2594)$ & $8.7 \times 13.9(28.5 \times 45.5)$ & 4 \\
\hline $297.9(3207)$ & $9.7 \times 15.4(31.75 \times 50.5)$ & 5 \\
\hline $418.1(4500)$ & $11.4 \times 18.3(37.5 \times 60.0)$ & 6 \\
\hline
\end{tabular}

These alternative building sizes are based on the U.S. Census' 2010 Characteristics of New Housing database. Figure 4-2 shows the percentile breakdown of the size of new single-family detached houses. More detailed information on the new housing data can be found in Figure 4-1 and Figure 4-2, which show the square footage frequency (left y-

\footnotetext{
${ }^{22}$ An EnergyPlus database can be created with location-specific information readily available.
} 
axis) and cumulative distribution (right y-axis) for 1-story and 2-story single-family homes, respectively. ${ }^{23}$ The building sizes selected for the residential prototypes represent the $10^{\text {th }}, 30^{\text {th }}, 50^{\text {th }}, 70^{\text {th }}$, and $90^{\text {th }}$ percentiles for each distribution.

Any design with $185.8 \mathrm{~m}^{2}\left(2000 \mathrm{ft}^{2}\right)$ or less of conditioned floor area is assumed to have 3 bedrooms. Any design with between $185.8 \mathrm{~m}^{2}\left(2000 \mathrm{ft}^{2}\right)$ and $278.7 \mathrm{~m}^{2}\left(3000 \mathrm{ft}^{2}\right)$ of conditioned floor area has 4 bedrooms. ${ }^{24}$ Any design with $278.7 \mathrm{~m}^{2}\left(3000 \mathrm{ft}^{2}\right)$ to $371.6 \mathrm{~m}^{2}$ $\left(4000 \mathrm{ft}^{2}\right)$ of conditioned floor area is assumed to have 5 bedrooms. Any design with greater than $371.6 \mathrm{~m}^{2}\left(4000 \mathrm{ft}^{2}\right)$ is assumed to have 6 bedrooms.

Table 4-2 Size Distribution of New Housing in Square Footage

\begin{tabular}{|r|r|r|}
\hline Percentile & 1-Story & 2-Story \\
\hline $10 \%$ & 1200 & 1600 \\
\hline $20 \%$ & 1398 & 1878 \\
\hline $30 \%$ & 1561 & 2152 \\
\hline $40 \%$ & 1706 & 2376 \\
\hline $50 \%$ & 1866 & 2600 \\
\hline $60 \%$ & 2052 & 2912 \\
\hline $70 \%$ & 2270 & 3246 \\
\hline $80 \%$ & 2592 & 3684 \\
\hline $90 \%$ & 3125 & 4493 \\
\hline
\end{tabular}

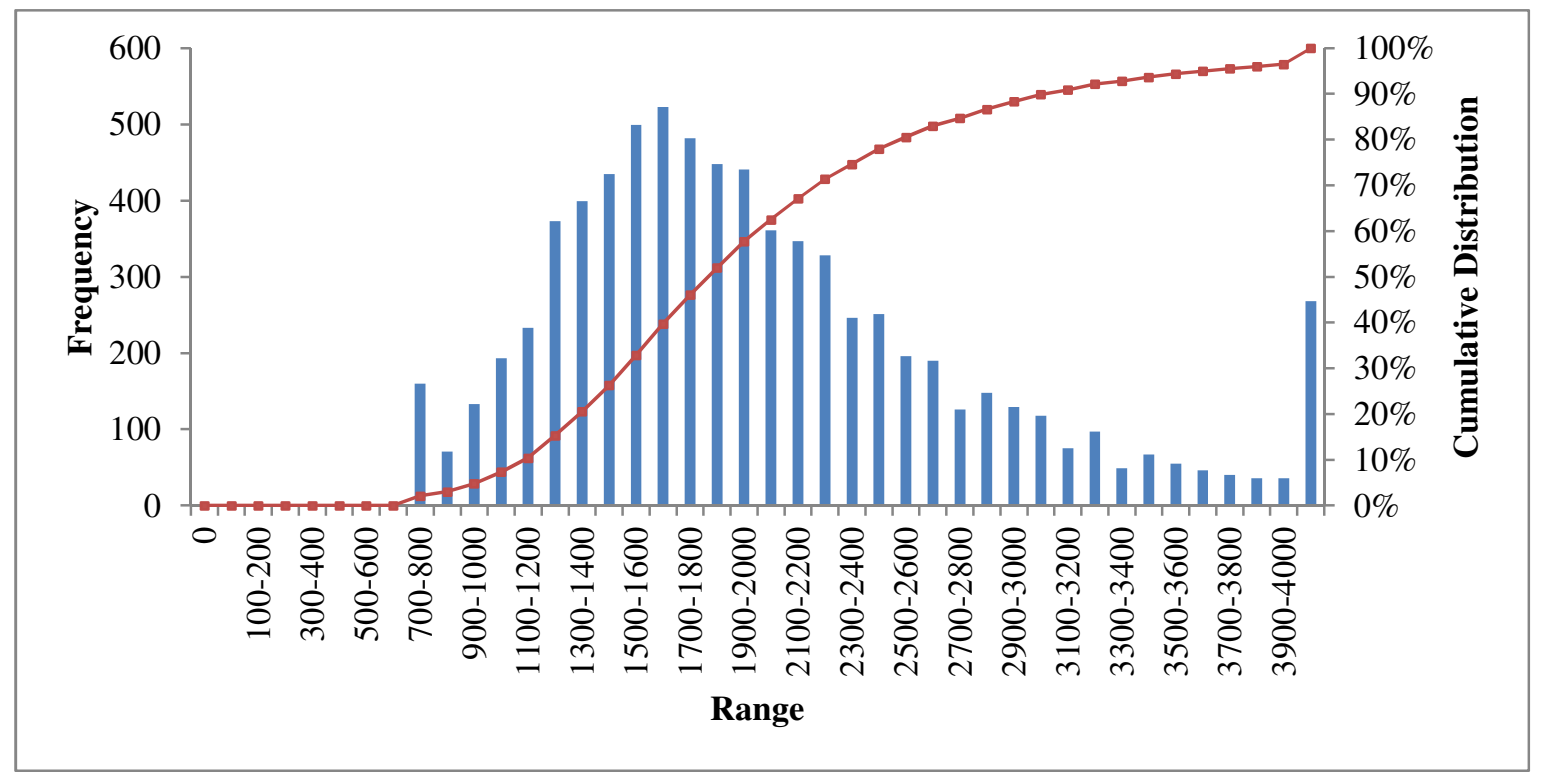

Figure 4-1 Square footage of new 1-story single-family housing

\footnotetext{
${ }^{23}$ Homes with less than 700 square feet are assumed to have 700 and square feet.

${ }^{24}$ Building dimensions and number of bedrooms are based on RECS and AHS data.
} 


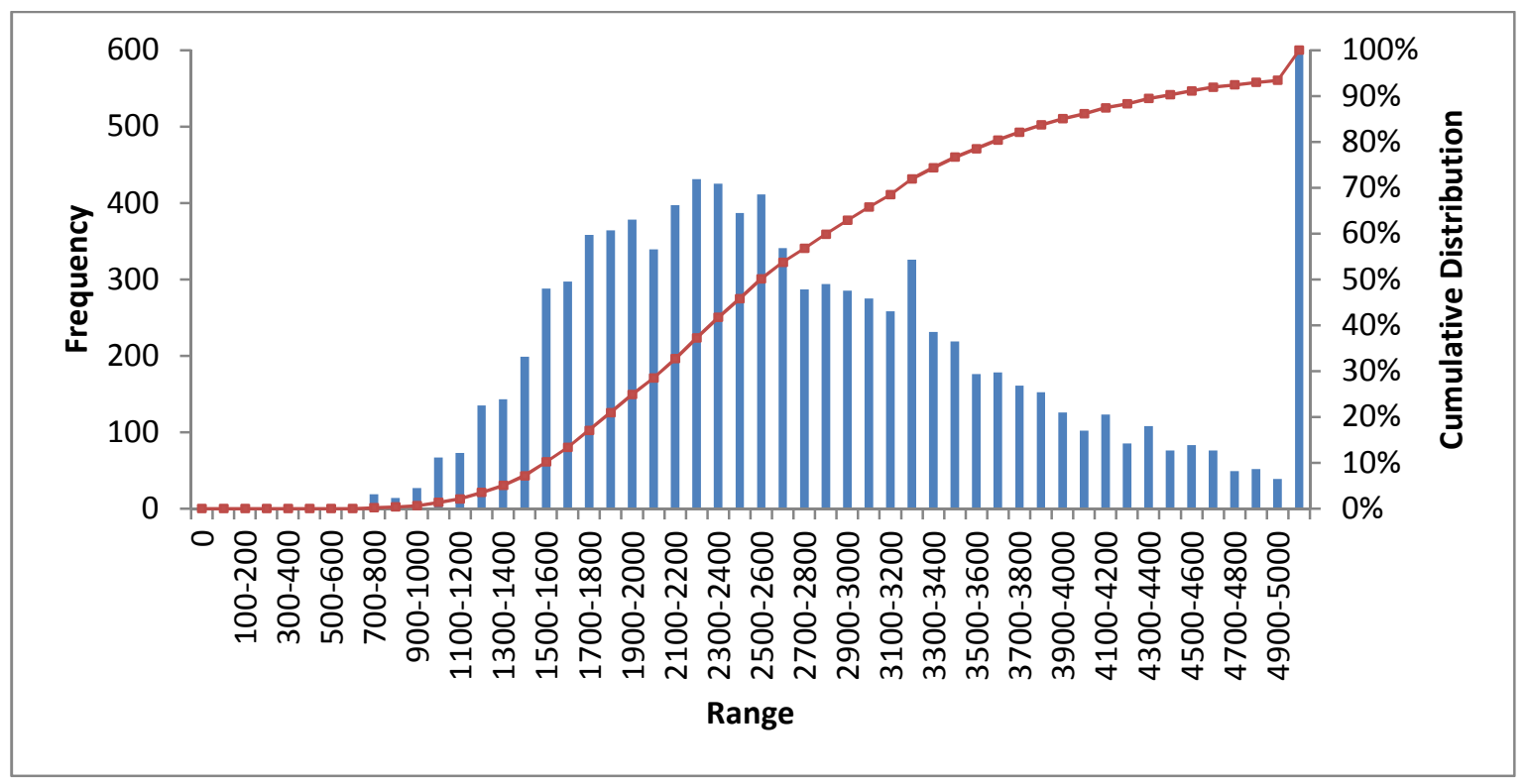

Figure 4-2 Square footage of new 2-story single-family housing

\subsection{Additional Building Designs}

The two prototype homes, oriented due south, can be altered in a number of ways to account for alternative building designs. A two-car garage can be added to various locations around the house (east, southeast, and southwest). ${ }^{25}$ New west, northwest, and northeast side designs can be created by changing the orientation of the house by 180 degrees.

Slab-on-grade is not the primary foundation type in some regions in the United States. Alternative foundation types can be added to the prototype designs to better represent the U.S. housing stock. The slab-on-grade can be replaced with slab-in-grade, crawlspace, or a basement (finished and unfinished).

\subsection{Heating Fuel Type}

Although natural gas is the most common heating fuel source in the nation, particular regions of the nation, such as the South, tend to use electricity at least as often as natural gas. Also, a significant portion of the homes in the Northeast use fuel oil for heating.

\subsection{Additional Energy Codes}

\footnotetext{
${ }^{25}$ The most typical garage in the housing stock is an attached two-car garage.
} 
The current number of prototype buildings, designed to comply with 2009 IECC, can be modified to meet older IECC codes -- 2000, 2003, and 2006 IECC-- to account for the variation in state energy codes across the United States.

\subsection{Parametric Designs beyond Current Code}

Once prototypes for current state energy codes have been created, parametric improvements can be simulated to estimate energy savings from additional energy efficiency improvements using conventional approaches as well as emerging technologies. 


\section{References}

American Society of Heating Refrigerating and Air-Conditioning Engineers, Inc., 2007, ANSI/ASHRAE Standard 62.2-2010, Ventilation and acceptable indoor air quality in low-rise residential buildings.

American Society of Heating Refrigerating and Air-Conditioning Engineers, Inc., 2007, ANI/ASHRAE Standard 90.2-2007, Energy-efficient design of low-rise residential buildings.

American Society of Heating Refrigerating and Air-Conditioning Engineers, Inc., 2009, ASHRAE handbook - fundamentals.

Department of Energy, Building Technologies Program, EnergyPlus energy simulation software Version 6.0.0, 2010, http://apps1.eere.energy.gov/buildings/energyplus/.

Energy Information Administration, Commercial building energy consumption survey, http://www.eia.doe.gov/emeu/cbecs/.

Energy Information Administration, Residential energy consumption survey, http://www.eia.doe.gov/emeu/recs/.

Field, K., Deru, M., Studer, D., August 2010, Using DOE commercial reference building for simulation studies, Conference paper, presented at SimBuild 2010, NREL/CP550-48588.

Hendron, R., Engebrecht, C., January 2010, Building America research benchmark definition, National Renewable Energy Laboratory, Technical Report NREL/TP550-47246.

Hendron, R., Engebrecht, C., September 2010, Building America house simulation protocols, National Renewable Energy Laboratory, Building Technologies Program.

International Code Council, 2009, International residential code for one- and two-family dwellings.

International Code Council, 2009, International energy conservation code.

Pacific Northwest National Laboratory, September 2009, Impacts of the 2009 IECC for residential buildings at state level, Department of Energy Building Energy Codes Program. 
Persily, A., Musser, A., Leber, D., August 2006, A collection of homes to represent the U.S. housing stock, National Institute of Standards and Technology, NISTIR 7330.

RSMeans, 2005, Square foot costs $-27^{\text {th }}$ annual edition, Reed construction data.

U.S. Census Bureau, National american housing survey, http://www.census.gov/hhes/www/housing/ahs/ahs.html.

U.S. Census Bureau, Manufacturing, Mining, and Construction Statistics Division, 2011, Annual 2010 characteristics of new housing, http://www.census.gov/const/www/charindex.html. 


\section{Appendix}

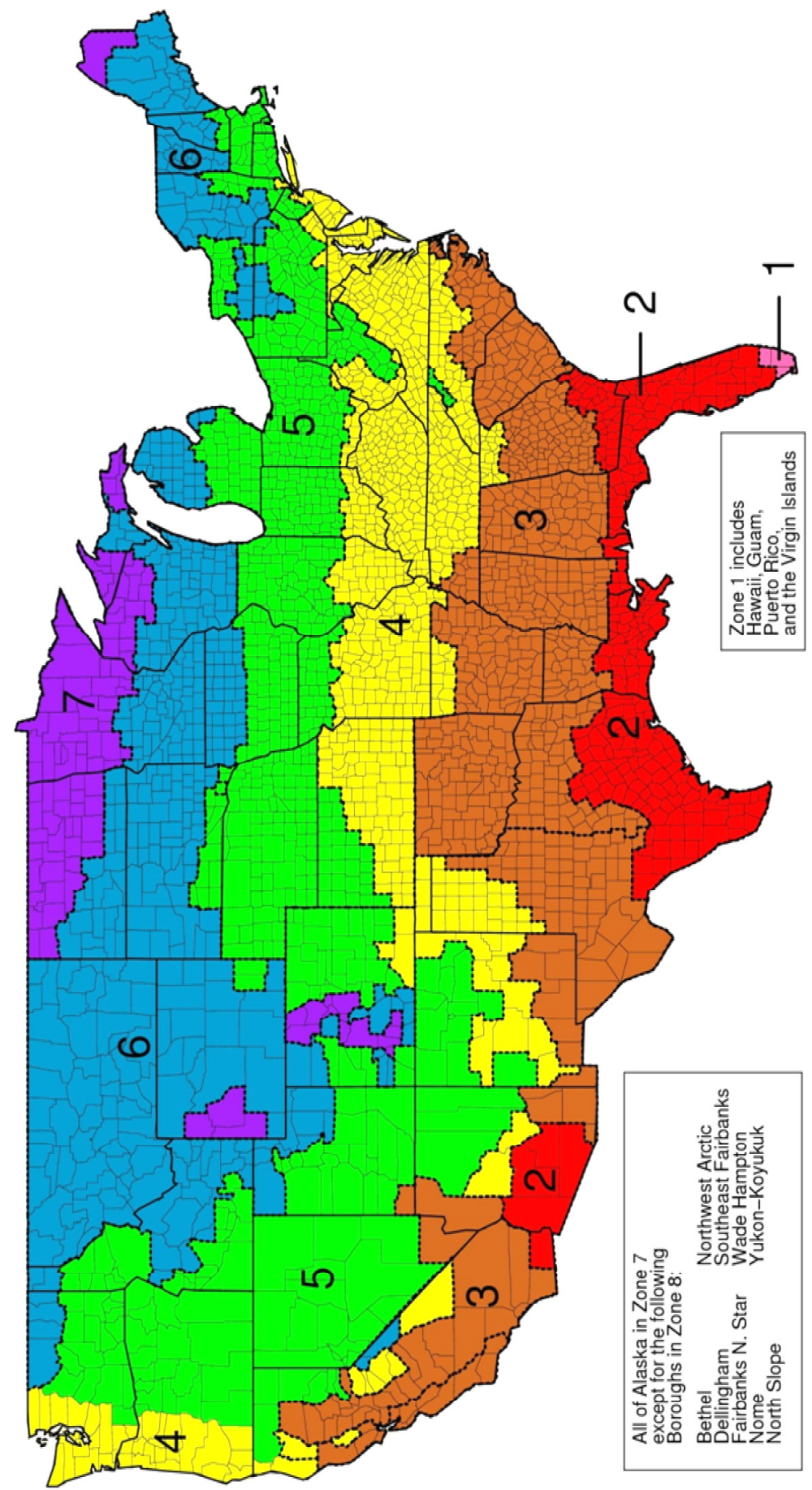

Figure 1 ASHRAE 90.1 Climate Zones by County 